\title{
予見できない問題の処理と AI の意義 Significance of AI in Solving Problems That Can Not Be Foreseen Beforehand
}

\author{
大須賀 節雄 \\ Setsuo Ohsuga \\ 東京大学名誉教授 \\ Emeritus Professor of University of Tokyo \\ ohsuga@fd.catv.ne.jp
}

Keywords: Multi-Strata-Model as conceptual modeling, automatic generation of information systems, aiding conceptual modeling, building-block approach of system generation, automatic programming

\section{Summary}

Problems in the world are classified into two classes; the ones that people can foresee to the details beforehand (to such an extent that making computer programs for solving them is possible) and the others. Because of very the nature of current information technology computers are used only for the former class problems but the latter problems are left to human without exception. Only possible method to deal with unforeseen problems in the latter class is to take trial-and-error approach. When an unforeseen problem comes arise, human tries to make a hypothetical solution and evaluate it. When the scale of problem gets large however, it becomes a very difficult task even for human. Recently, the number and the scale of the latter class problems are increasing. It is anticipated that in near future they go beyond human capability. Then no one can deal with these problems satisfactory and it is expected that many troubles happen to be. An innovative technology is required to deal with these problems in order to avoid the troubles. It is expected that computers have potential to contribute in this process by undertaking evaluation of the hypothesis. Since however the problems are not foreseen beforehand, it is not possible to provide any specific method suited for evaluating the hypothesis in advance. Automatic and dynamic generation of evaluation system in real time is necessary as an innovative information technology. The major objective of this paper is therefore to discuss such an information technology that can aid human trial-and-error approach. An analysis of the process of solving unforeseen problems and a method of generating automatically information systems for evaluation are discussed.

\section{1. はじめに}

人間同士が真に理解しあえる状況を，「共通の言葉を もつ」という言い方をする . 文学的な言い方で , 他に言 い樣がないためにやむを得ずこのように表現されている が , これが表す意味は深い .ここで使われている「言葉」 は狭い意味での言語ではなく，むしろ共通体験や知識の ようなものである . 同じ言語 , 例えば日本語を使ってい ても表層的にしか理解し合えない人間同士は非常に多い . 弚れに対しこの意味するところは, 表現の表層的な意味 に拘わらず, 話者の意図を, 光の奥深い理由や内容に至 るまで正しく理解することができることである .このた めに会話者は話題とする共通の世界モデルを持ち，夋の 解釈のために共通の文化的背景すなわち深い知識を持た ねばならない . さらに一連の会話は異なる話題あるいは 要素から構成されている . 個々の要素は世界を一つの視 点から見た側面であり，会話の進行に応じてこの視点が 変動するので, 会話の世界を乥れに応じて動的に自動構
築できねばならない . ただしこの機能は世界のあらゆる 側面をカバーする必要はない，一連の会話が成り立つ範 囲でこれが保証されれば良い .

人間同士の会話でこの樣なコミュニケーションがど の程度理想的に行われているかを測ることは難しい．理 解の正しさを客観的に評価することが困難だからである . これは個人としての文化的背景や理解の深さに関わり， かつ対話者の相対的なレベルにも関わるからである．し かしこの樣な会話ができることがコミュニケーションの 理想であることに変りはない．

これは当事者の一方が情報システムであっても同樣 である．人間と機械のコミュニケーションの究極はこの 樣な理解が両者間で成り立つことであろう．事実，人間 同士の場合と同じ枠組みが不可欠なコンピュータ応用が 存在する . 後に述べるように , これは前もって問題の詳 細を知ることができない(従って処理プログラムを準備 しておくことができない) 問題である .この樣な例とし てシステム開発や介護ロボットを挙げておこう.これら 
は上記のようなコミュニケーションを人間一機械間で実 現するための創造的な情報技術を必要とする .これにつ いては後に述べるとして , 上記のコミュニケーションを 可能にするための枠組みとして，

(1) 世界モデル,

(2) 背景知識,

（３）視点変動による関連背景知識の自動調整機能, を挙げよう．言うまでもなくコミュニケーションの前提 として(狭義の) 訃語がなくてはならず, 言語の意味を 共有するためにオントロジーが必要である . これらはコ ミュニケーションの基盤であり，既に多くの議論がなさ れてきているから，ここでは既に満たされているとしよ う．本稿の本旨は理想的なコミュニケーションにはこれ だけでは不十分であり，乥の上に上記の仕掛けの必要性 を主張することである．

人間一機械間の応用問題解決については, これはコミ ユニケーションの基盤技術と応用の中間に, 上記の枠組 みで実現されるもう一つの技術レイヤーが必要であるこ とを意味する.情報処理という観点で見れば（1）の世 界モデルや ( 2 ) の背景知識はデータであり，これらの 質と量が会話の質やレベルに関わる ．（３）の調整機能は 処理機能である.ここで重要なことは, 視点変動に応じ て必要な知識の調整は自動的に行われねばならないこと で,もしこの段階に人間が介入せねばならないとしたら， 例えばモデルの解釈に人間か関与せねばならないとした ら，会話は光の都度途切れてしまうからである. 処理機 能を状況に適応して動的かつ自律的に生成すること，す なわち自律適応性が核心であり最も困難な点である .

この状況を明らかにするため，一般的に現在の技術と 比較してみよう. 現在のいかなる技術も，自律性を前面 に出すと前もって定めた通りの行動を行う非適応型ある いは[押し付け型]にならざるを得ず，適応性を主にする と予め準備された行為を人間の指示に応じて実行する非 自律型にならざるを得ない .いずれの場合も将来予想さ れる問題に対応できない．

自律適応型の人間一機械間コミュニケーションで人 間同士のように文化的な理解を伴う会話を目指すことは 可能であるが，上述したように，この時は理解の正しさ を客観的に評価することが困難である．従って当面の考 察範囲を； 対象とする世界モデルが物理的な物に関す る範囲'に限定しよう.この場合，理解の正しさは；コ ミュニケーションを通して, 対象世界の要求された変化 あるいは状態を満たすように対象への働きかけが正しく なされるか否がによって客観的な評価が可能になる． さらに上記の枠組み内の情報の質, さらには枠組み自体 か評価される．これを情報技術の一つの目標として，現 状を見てみよう。

今日の情報技術はネットワーク技術との結合によっ て広域情報網を実現し，大きな発展を遂げている．しか し現実を直視するなら，これによってソフトウエア技術
として創造的な進化がおこなわれている訳ではない，広 域化と通信量の増大効果か際だっているに過ぎないと言 える.これらは現代社会が直面している真の問題一光こ にこ光自律適応性のような創造的な情報技術が強く期待 されている分野一から人々の関心を転じてしまっている． この状況は人工知能研究とて例外ではない. かつて多く の人工知能研究者の研究目標は, 「人間と類似の統合的 知的機能を持つ情報システムの開発」にあった . しかし エキスパート・システム研究の挫折により，近年は統合 的知能の情報化技術が後退し, 研究対象が要素的知的機 能の解明と弚のモデル化に偏っている感がある.

優れた知能を実現する上で優れた要素知能が不可欠 である.機械知能も, より高度な要素機能の研究が重要 であることは言うまでもない．しかし認識であれ，推論 であれ，あるいは発見であれ，いかに優れたものであっ ても要素技術が単独て現実の問題を解決することは少な い. 人間には多樣な知的機能が備わっているが, 置かれ た状況に応じて適切な判断の下に, 樣々な要素的な知能 を統合することによって，困難な状況への対応を可能に している.乥こに我々は高度の知能を見る.人工知能も 同樣であり，状況に応じて多くの要素を自律的に統合す ることによって始めて環境や目的の多栐性に対応する機 械知能の発揮が可能になるし，統合化の機能が有って初 めて要素機能が生きてくる[ROS 97, OHS 01] .

一方，先進的情報技術への期待あるいは社会的な二ー ズと言う点では，統合化は極めて重要な課題である。例 えは環境, 安全, 福祉, 産業谷の他の現実世界の多くの 分野で大規模化によって計画・開発・管理等が困難にな るという問題への対策や, 介護ロボットのような新しい 技術目標の達成が必要になっている.これまでは人間が 問題の把握と, 新計画・開発の見通しを立ててきた .し かし対象の大型化に伴って，全体を正しく見通すことが 極めて困難になって来ている．近年発生している各種大 型の事故 (例えば原子カプラントの事故 , 医療事故 , 米 国における停電の発生など) の原因は突き詰めてゆけば この問題に突き当たる.これを避けるために開発計画の アセスメントの重要性が強調されるが, 見通しが困難な 問題を人間自身か評価することは困難である.情報技術 を導入しょうとしても，今日の技術では未知の対象に対 して情報システムを開発することは困難である．すなわ ち現代の問題は， ( A ) 未知問題の計画・概案を作成する ために情報技術を導入したいが， (B) 計画・概案が前も って確定されていない限り情報システムか開発できない， という矛盾を含む .これをここでは「計画のジレンマ」 と呼ぼう．この困難の要因を分析し, 解決に寄与する新 しい情報技術を開発することは人工知能に課せられた大 きな課題である。

未知問題の計画・概案を確定する唯一のフォーマルな 方式は試行錯誤である . 従ってこの課題は試行錯誤の過 程に組み込むことのできる情報システムを開発すること 
である . 仮説を作るのは主として人間であり，情報シス テムの役割は仮説の正しさを検証することである．作ら れる仮説が異なれば要求される情報システムの機能も異 なる．しかも仮説は動的に作り替えられ，光の範囲を前 もって全て予測し，前もって準備しておくことは困難で ある. 弚こで状況に応じて情報システムの自動生成が必 要になる . 情報システムへのこの要求は冒頭のコミュニ ケーションにおける (3) の機能に相当するものである .

コミュニケーションにおいて会話の流れを中断しな い為に会話世界の自動構築が必要であると同樣に, 問題 解決においても試行錯誤の過程を支援する情報システム は流れを中断しないよう，既存の機能を自律的に統合す ることによって必要な機能を生成する機能が必要である． これが今日の情報技術のネックになる . 例えば統合を特 徵としてうたっているIMS[YOS 03]の技術でも，目的に 合わせて機能の統合計画を作るのは人間である .

処理機能を動的に自動生成する方式としては, データ としての知識 (背景知識) を素材にして知識構造を自動 的に構築し, 弚れを直接動作化するか, あるいは処理系 に変換することが最も有力である.生成に際しては光の 機能が適用される対象 (世界モデル) が明示的に存在す ることが必須条件である .これは前記コミュニケーショ ンの枠組みと同じである .

この方式の特徵は「予見できない現実のニーズに直接， 統合的に対応するソフトウエア技術」を実現することで ある．「予見できない状況に統合的に対応すること」が要 求される問題はシステム開発の外にも介護ロボットや宇 宙システムの保守, 自動車のリアルタイム診断等で現実 的なものになってきている.このような質的に高いレべ ルの情報技術には人工知能の技術が不可欠であり，多く の努力を傾けるべき課題である .

自動化には, 弚れに必要な全ての情報を情報システム が保有することが前提である．これが対象のモデル (前 記会話世界のモデル) と行為を自動構築する素材として の知識である . この方式は, 人間か㳔象のモデルと問題 解決の要素知識を持っていてコンピュータの機能統合を 指示する現在の「人間指示による機能統合」に代わり， コンピュータが対象のモデルと知識を持ち, 自身で機能 統合を行う「コンピュータ自律機能統合」である . 大規 模問題では対象の中に人間が含まれるから，人間を含む モデルの表現を定式化することが必要である．この意味 については後により詳細に述べるが，これを知的な情報 システムのあり方とする[1] . 以下では, 人工知能を主と する新しい情報技術の必要性と, これを達成する一つの 方式について論じる .

\section{2. 知的情報技術の意義 - 技術開発 の場合}

このような新情報技術の実現を目指して，まず新情報 技術の意義をより具体的にしよう．これを端的に表す例 として近い将来大きな問題となることが予想される技術 開発問題を説明の導入部として取り上げる,開発問題は， *創造的な仕事である，*多要素から成る複雑系である (分散的処理)，*人間関わる, *多分野に関わる,* 制約事項が多い(環境, 保有設備, 保有技術, 経験, 法 規，乥の他)，*正しいという確認が取れない=原案に基 づいて評価が出来ない, などの要因で対象が大型化する と共に困難度を増している．ソフトウエア開発もこの一 つであることは言うまでもない[WAY94] .これを支援す ることが重要になっている .

情報技術とりわけ人工知能のように人間に最も近い 領域の情報研究は人間の知的活動を分析し, 定型化する ことが重要である . 人間の知的活動は応用に近づくほど 統合的になるが, 弚の活動内容は多くの場合対象依存で ある. 従って応用分野について十分理解しない限り, 光 こで行われている統合的情報機能について理解すること ができない．しかし統合的情報機能の研究を目指して応 用分野について学ぶことは情報技術研究になりにくかっ た . 情報技術を理解した応用分野技術者になり得ても， 普遍性を求める情報技術の成果には成らないからである. これが知的情報統合の研究を困難にしてきた．学会論文 として応用研究が重要であるという声はこれまでもしば しば聞かれたが，光れが実際に困難であった主たる原因 がここにある．

しかし，前章で述べた統合的情報機能は，このように 特定応用分野に特化した個別統合機能ではない. 多分野 の対象について，適用される個々の分野か指定されれば 分野依存の情報システムを生成する汎用の機能，すなわ ちメ久機能を実現する方法論である．このようなメタ方 法論は人間の世界では珍しいものではない . 代表的なの は科学的方法論で, これは広い分野に適用可能な普遍性 を持っている .もし上記統合化のメ夕機能を情報技術と して実現する方法が見いだされれば，普遍的方法論とし て広い範囲の応用を持つ。

コンピュータが方法論を持ち問題解決を自己管理す る効果は非常に大きい . 各応用分野がこの成果の効用を 理解し，情報技術と応用分野技術の協調がより積極的に 進められることが期待される．すなわち「コンピュータ 自律機能統合」か情報技術における重要な研究対象に成 り得る、言うまでもなく，この樣な方法論を情報システ ム内に実現することは容易ではない，以下光のような新 しい情報技術の意義と効用を述べ，さらに光れを実現す るための要求と技術について述べる. 


\section{1 技術開発における情報技術の利用}

個々の分野ごとに分野依存の情報システムを人間が 产の都度開発するものと, 汎用情報システムが分野依存 の情報システムを自動生成するメタ機能の違い，および そのような情報システム開発の重要性を，技術開発支援 を例にとって述べる .これは説明のための例であるが， メ夕機能の重要性は現実のものになっていることか理解 されよう.

メ夕機能ではないが，情報技術が一般の技術開発に利 用されている既存の例として C A D / C A Eが代表的で ある.CA D / C A E の概念は機械, 電子・電気, 材料な ど分野によらないが, 作られるソフトウエアは分野によ って異なる . 以下の議論では便宜上説明例として機械分 野を想定するが , 考え方は他の分野についても全く同樣 である .これは人間の用いる設計の方法論の一部を定式 化し，情報技術で実現したものである．この方法論は対 象の形を定義・表現する部分と, 兴の構造によって定ま る機能・性能を評価する部分から成る (図 1 ) .設計の情 報化にとって要求されるのは，

(A)設計対象を必要な処置が可能な形式で表現すること，

(B) 光の表現に対して必要な処理を行うプログラムを準 備すること

である . (A) で作られる表現を製品モデルあるいは対象 モデル (以下単にモデル) と呼ぶ . モデルは要求される 処理の内容を考慮して作られる . (B) のプログラムは原 則的には 3 種ある.第 1 は表示装置上に対象を可視的に 表示するもの，第 2 はモデルから対象の性質や機能を見 いだすもの，第 3 はモデルから製造情報を生成するため のもの，である .この3種のうちどこまで実装されるか はモデルの表現法による .これは一般にデータベースと して実現される．しかし今日用いられているデータベー スの形式化の枠組みは単純なものであり，C A D / C A E の適用範囲はこの形式化が可能な範囲に制約される . 分 野ごとに炎れに適した形式化が必要になるため機械, 電 子・電気，材料など分野依存のものになっている．今日 のデータベースの枠組みでは1章で述べた条件を満たす ことができない .

一方，弚の制約があるが故に，CA D / C A E のシス テムは個々の適用対象とは無関係に前もって作ることが できる . 必要なときに支援システムを作るのではなく， 既存のものを使えることは応用上重要な条件である .

しかし技術開発の全過程で見ると今日のＣＡＤ／C $\mathrm{A} E$ の効用は大きなものではない，技術開発は樣々な段 階からなるがC A D / C A E が使われるのは下流過程の 部品開発のレベルであり，このレベルに至るまでの上流 の仕事の比重が大きくなっているからである. 現行 C A D / C A E の技術をさらに拡大して产の部分をカバーす ることは困難である．弚れは上流過程の仕事が要求する 内容が質的に高度で, 単純な形式のデータベースと午の

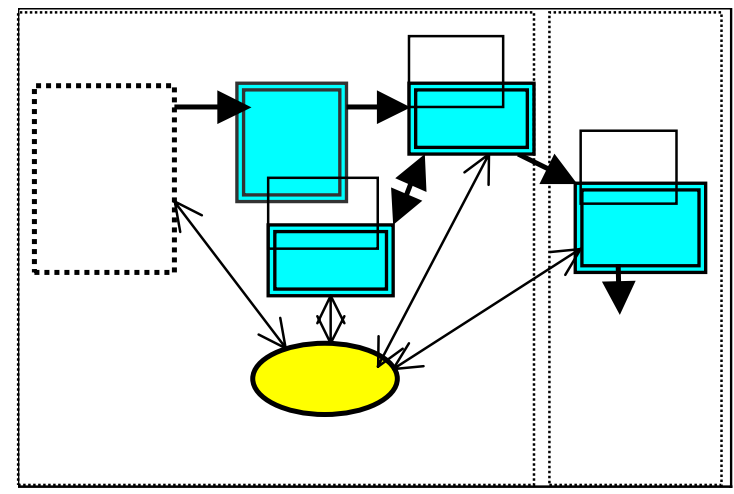

図 1 設計製造の手順と C A D / C A E ／C A M の位置づけ

処理プログラムを基本とする現在の情報処理技術の枠組 み内でプログラムを工夫すると言った方法では対応でき ないからである .これは現在の技術開発支援ソフトウエ ア技術の限界であり，この限界を超えるには従来とは異 質のレベルの高い情報技術が必要である．情報技術の力 バー範囲は情報技術のレベルによるからである．

技術開発の全過程と炎の中で今日のCA D / C A E がカバーする範囲を示したものが図 2 である . 開発の目 的は指定した機能・性能を持った「何ものか」を実現す ることであり，これが全体の要求である．技術開発の場 合の「何ものか」は「物」としての製品であるが，一般 には必ずしも光れに限定されない．方法や組織あるいは 行為など，より抽象的ものであっても良い．これを以下 では「開発の対象」,あるいは単に「対象」という.対象 は開発のスタート時点では存在しない .これを具体化す ること, 光の形状や部品・要素から作られる構造・組織 を作り出すことが開発である．

「概念設計」はいかにして光のような対象を作り出す かについて全体の構想を表す構造を作るものである .こ れはいわば開発の基本方針であり，方針の決め方により 以後の作業も全く異なるものになる . 以後の作業内容の 大筋がこれで定まり，開発の成否の多くがこれにかかっ ている.

「技術設計」はこの概案が技術的に実現可能かどうか を検証し，あるいは技術的に実現可能なように対象の構 造を定める . 一般に大規模開発では作られる対象も複杂倠 になり，技術設計は全体から細部に至る多くの段階で行 われるのでこの部分の作業範囲は大きい .

「詳細設計」はこれによって定まる全体構造を，入手 可能な部品を用いて実現可能なように，まだ詳細化され ていない細部までを定める .

「製造」はこの情報を, 求められている何ものか、に 変換する過程である. 対象が物理的な物である場合，こ の情報から実際の物を生成する.この後，これが当初の 要求を正しく満たしているかを検証 (「検査」)し，「出荷」 される . 


\section{要求}

計画·立案->概念設計-> 技術設計->詳細設計->製造->検査->出荷

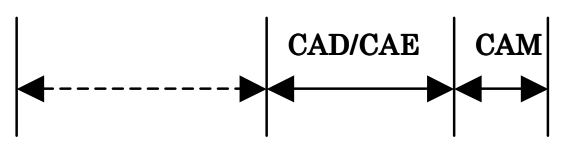

図 2 技術開発過程

この過程の中で概念設計が極めて重要である．概念設 計から技術設計の上部に至る部分で開発の成否の $70 \%$ 以上が定まると言われる．CA D / C A Eがカバーする 範囲は技術設計の一部と詳細設計に留まる.

概念設計の影響は対象が複杂倠になるほど大きくなる． この細部は個々の分野・ケースによって異なるが, 基本 は要求機能を満たす構造を見いだすことである .この基 本原則は“可能な全ての対象構造の中から，利用可能な 情報 (知識) あるいは他の評価手段を用いて最適なもの を選ぶ”というものである. 実際には可能な全ての対象 構造を並列的に全て作ることは困難かつ非効率的で，こ れを可能にする実際的な方式がとられる．

多くの場合, 複杂隹な要求を満たす複杂隹な構造を一度で 見いだすことは困難で, まず要求機能を小要求の組に展 開して詳細化し, 個々の小要求機能を満たす対象構造を 求め, あるいはさらに小要求機能を展開するという多段 の方式プロセスが取られる .この結果作り出される対象 も多階層の構造になる .この作り方にトップダウン方式 やボトムアップ方式など異なるアプローチがある．いず れの方式に関わらず, 作業の単位は‘ 上位の要求を満た すように, 直下の複数部品の機能と光れらの構造関係を 定めること’ である . 兴のような小構造からなる作業を どのような順序で行うかは人が動的に決めるので, 支援 情報システムは光れに対応せねばならない .

個々の作業単位については‘一つ (または少数) の構 造を仮説として作り，光れを評価して不適切なら作り替 える'と言う試行錯誤が行われる.これら小構造が相互 に関連付けられながら全体構造を形成してゆく．この段 階の対象構造は適切と思われているが, 未だ最終評価が なされていないものである .これを設計者の概念を表す ものとして概念構造と呼ぼう . この階層構造の中で最上 位に近い構造部分は光れより下位の構造の大要を定め, 作業内容の大筋がこれで決まる . この選択には大きな自 由度があり設計者の考え方が大きく反映される部分であ るので，特にこの部分を (狭義の) 概念設計と呼ぶ．

このことを例で示す．離島間の新しい乗り物を設計す る場合を想定しよう．この場合主設計者が問題解決者で あり，「新しい乗り物」が対象で,弚の構造が末知である. 設計に際しては所要速度(時間) 乗り心地(摇れ 騒音), 安全性, 製造コス卜, 運用コスト, 運用・管理条件 (荒 天時の運用等), 法規など, 利用目的 (軍用, 民用等) や
状況 (港湾の状況等) によって定まる要求や制約条件が 多数あり，これらを満たすように，これまでの樣々な知 見を参照しながら対象の構造を細部まで定めるのか設計 問題解決である.可能性のある方式として, 通常船方式, 水中翼船方式, 潜水船方式, 水面浮上 (ホバークラフト) 方式水上飛行機などがあり, まず仮案として基本方式と 概略の構成を作る . 例えばジェット機のようなターボエ ンジンを用いた水中翼船方式を採用するとしよう．対象 の基本構造は, 水中翼船に関する知識から，「船体」,「エ ンジン」,「水中翼」等から構成されるものとし, 次いで 対象自体の諸要求を満たすように, 個々の部分 (アセン ブリ) の性能や相互の構造関係を定める .このように基 本方式を定める部分が概念設計であり，この決定により 以後の設計方向が定まる . 個々のアセンブリの性能は, “光れらが満たされればそれから構成される対象の要求 が満たされる’ものとして仮に定められる要求性能であ る .ここまでの検討の結果, 要求が達成される可能性が 高いと考えられれば概念設計が (仮に) 終了し，個々の アセンブリについて, 上で与えられた要求機能を満たす ように ,下流部分の設計が始まる この下流部分の設計， 例えばエンジン設計は別の専門家に委託される場合が多 い.このような分業が可能なことによって始めて大規模 な開発が可能になる .この時 , この部分以下の設計がど のように進められるかについて, 上記の主設計者は完全 には見通せない．これは「上位の設計 (問題解決) 結果 に応じて下位の設計問題が定まる」動的な問題解決であ る。

\section{2 概念構造の形成例}

図 2では処理の流れのみを示したが，これに伴って概 念構造が作られてゆく . 状況をさらに明確にするために 概念構造の表現を考える.一般にこの作成例を作ること は困難な作業である．枠組みは普遍的なものであるが， これでは抽象的な議論に終わる. 話題を具体的にするに は分野固有の情報に基づく特定の構造を作らねばならず， 分野の専門性が要求されるからである .ここでは単純化 して示す。

図 3 は前記離島間海上交通システムの例である（もち ろん実際の概念構造はこのように単純なものではない). この図では開発の開始時 (同図 (a)),第1段の終了時点 (同図 (b))，および概念設計終了近く(同図 (c)) の概 念構造を示している. 開発責任者は開始時には未だ情報 としても存在しない開発問題を持つのみである .これか ら第1段階の構造を作る。この過程において, 前述した ように，樣々な代替案がある．乥れらの中から水中翼船 方式が選ばれたとしよう.以後，作業が順次下方に進行 する . 大規模な，あるいは複杂隹な対象ではこの全体を一 人の人間が行うことは不可能で, 多くの専門家が協調し てこの構造を作り上げる . 例えば $\mathrm{A} は$ は海上交通シス テム全体を輸送手段, 運用システム , 保守システム , 等 
から構成するように基本構造を決め，光れぞれの機能・ 性能と これら各サブシステム間の関係を，「乥れらが達 成されれば全体の海上輸送システムに対する要求が満た される」ように定める。次いで尃門家 B，C，Dを選定 し, 以後の仕事を任せる.ここまでがAの役割である . 次いで専門家 B，C，Dは光れ光れ与えられた条件を満 たすようにサブシステム開発を行う．例えばBは与えら れた機能・性能の輸送手段を水中翼船方式で実現するこ とを目的とし，船体，エンジン，水中翼などのサブシス

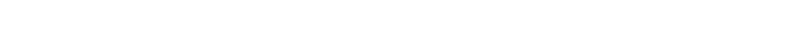
らの関係を定め，以後の作業を専門家 $E ， F ， G$ に任せ る.このようにして，Aの決定に基づいてサブシステム の構造が定まり, 弚れに応じてさらに下位の構造が決定 されてゆく.この展開は上位の複数の異なる要求を分散 することである．下位のサブシステムへの要求はより単 純なものになり，光れを満たす作業は，より単純な，実 現しやすいものになる．A，B，‥Gの作業のパター ンは類似て割り当てられた範囲の作業（これを作業単位 と呼ぶ）を実行する．個々の作業では可能な限り過去の 事例を参照し, 数值的計算あるいはシミュレーションに よって構造の妥当性を評価せねばならない，各作業単位 か対象とする概念構造の部分 (範囲) を概念構造要素と 呼ぶことにしょう。

（a）開発開始時

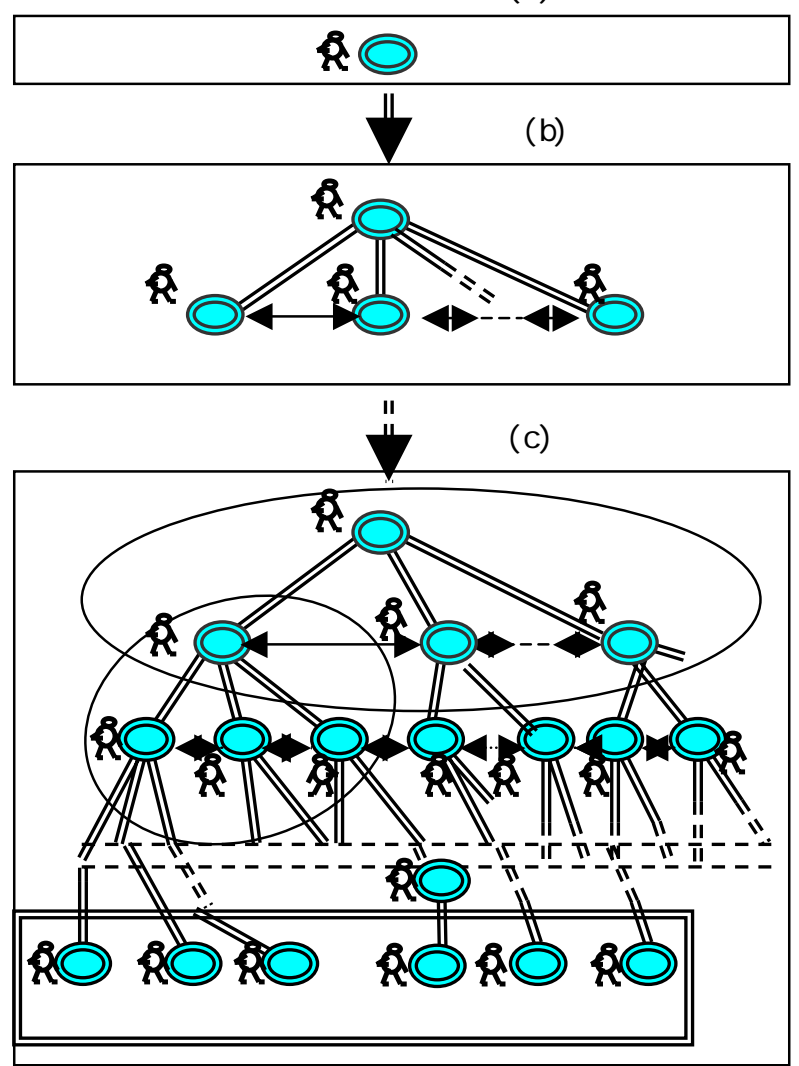

(1); 対象/要素

$\bigcirc ; 1$ 作業単位の範囲

図 3 概念構造の形成
開発の各段階で, 与えられた条件を満たすようにサブ システムの構造を決定することは容易ではない .このた めに必要な情報を収集し，サブシステム構造を評価する などの支援システムが不可欠である . また , サブシステ ムへの要求決定後, 弚れらサブシステムの下位構造を要 求通り実現する能力を備えた人物を選ばねばならない。

この選定も重要であり，光の作業を支援する情報シス テムが必要になる . 例えばこのシステムは, サブシステ ムの下位の構造決定に際して関連する技術分野を推定し， 弚れらの分野に関して十分な知識を持つ人物をこのサブ システムの担当者として選定するのに必要な情報を提供 するなどで，担当者を助ける. 個々の作業単位のパター ンは類似であっても要求内容は異なるから，これを情報 システムが支援するとしたら，同じ枠組みで，個々の作 業内容は全く異なる処理方式が要求される.これが冒頭 に述べたコミュニケーションの (3) と同じ機能が要求さ れる所以である .

图 3 は開発手順の原理を示したもので, 現実にはこの ように最初から全て新しく作り上げることは少なく, 可 能な限り前例を用い, 变更する部分についてのみ新しく 構造を作る. 変更部分に関連する部分も影響を受けるか ら，実際には大きな範囲を見直す必要があり，また担当 者の選定は新たに行わねばならないが, 基本構造の多く に前例を用いることによって効率的な開発が行われる． 変更する部分と光れに影響される範囲は開発目的によっ て異なるから支援システムとしてはこれに対応できねば ならない .

これら作業単位のパターンか類似であること，弚の実 行時において各作業単位は半独立性（相互関連を考慮し ながら自己完結的に作業が行われる) を保つことによっ て作業順序の任意性を保つこと, 上記前例の利用におけ る柔軟な作業範囲の指定に対応すること，は支援システ ムの構造を示唆している. 弚れは個々の作業単位ごとに 個別支援システムが形成され，これら複数の個別支援シ ステムが概念構造に応じて関連つけられた構造を持つシ ステム, このシステム内で各個別支援システムは分散し て独立にかつ連携的に動作することにより，人間の発想 を妨げることなく,個々の作業が必要とする問題解決(試 行錯誤の実行）を支援することができるようなシステム である. これは個別作業単位の要求する内容に応じて自 律的に生成されるエージェント・システムが, 概念構造 と同型に構造化されるマルチ・エージェント・システム の形態である[HUH 97 , SYC 98 , ARA 01] .ここには 2 つの解決されねばならない問題がある.一つは個々の エージェント・システムの自動生成方式, もう一つはこ れらエージェント・システム同志の自律的協調関係であ る.第 1 については本稿の主題としてこれまで述べてき たが, 以下の章でさらに考察する. 第 2 はマルチ・エー ジェント・システムの一般的な基本問題の一つであるか らここで特に取り上げる話題ではないが, 各エージェン 
ト・システムは実際の処理に際して多くのプログラムを 必要とし，これを，Webサービスを利用する等，可能な 限り既存の処理系を利用することを考えねばならない [KON 01].第 2 の問題はこれを考慮してェージェント・ システムを自動生成する条件を考慮することにある．

\section{3 新しい情報システムの意義一支援システ 么の目的と情報技術開発のあり方}

支援システムの詳細に入る前に, 新しい情報システム の意義をより明確にするために, 開発過程における支援 システムの果たす役割を示しておく．図３は既に全体が 見えていて，大きな困難は無い例であるが，概念設計の 難しさの一つは, 対象の規模が大きくなるにつれ, 要求 機能が多面的になり, 対象構造を決める段階で, 下位の 構造が見通せない為に生じる . 上述したように , 少し大 きな対象に成ると, 概念設計の担当者と個々のアセンブ リ設計の担当者は一般には異なる．概念設計の結果によ って下位のアセンブリ設計が異なるから，原理的にはア センブリ設計の担当者は概念設計が終了した段階で定ま ることになる . すなわち, 行為主体である設計者も, 上 位段階の問題解決の結果によって定まる. 現実には概念 レベルで従来と大きく異なる革新的な設計が行われる場 合は少なく, 概念構造も大半は以前の事例を用いる場合 が多い. 主体である人間の組織が大幅に変わることも少 ない. しかし技術革新の時代には新しい技術が今後増加 する可能性が高く，概念構造の動的構成の必要性が高く なっている .

上位の決定が下位動作範囲を決めるという動的な構 造構築が行われるのは技術開発の場合のみではない．人 間組織において下位の作業の割り振りを光れ光れの責任 者に委ねる場合も同樣で, 経営管理で上位の人間には下 位の作業の細部は見通せないという類似の状況が起きる．

もし, 概念構造の作り方が個々の応用分野に固有で， 分野ごとにすべて異なるものであったら，これは $100 \%$ 応用分野の専門家のなすべき仕事になり，情報技術者が 関与する余地はない．これが従来の考え方であり，特に 概念設計には方法論はなく, 個人の直感的能力と経験に 待つほかないと信じられてきた . 現実には概念構造の作 り方には多くの分野に共通性がある. 分野の専門的情報 が効果を挙げるのは作られた概念構造の評価の段階であ り, 概念構造の作り方自体は, 評価を内部に取り込んだ 試行錯誤である . これを定型化すれば汎用的な概念設計 支援の方法論としての枠組みになる. 谷の中の評価部分 に分野の専門的情報を利用することにより，結果は分野 固有のものになる .これは枠組みと光の内容の違いであ る. 応用分野と情報技術分野の境界は従来考えられてき たように概念構造が作られた後にあるのではなく，概念 構造の製作過程にある。

これを図 4 に示す. 図 4 (a)は現在の開発方式である. 開発の構想を作る段階は結果の検証方法がなく, 開発者
の考えが炎のままチェックされることなく実現される . 下流過程の技術設計から詳細設計の段階は要求の範囲が 狭まり，作業範囲も絞られるのでC A D / C A E により 設計・評価を行いながら作業が進められる部分で, 兴の 分誤りは少ない．これに対し上流の部分では正当性が保 証されていない，いかなる場合でも, 製品のトラブル等 が発生した場合, 前段に戻って改良がなされるが, 原因 が概念レベルの決定にある場合, 致命的な結果に成るこ とが多い．これを防ぐには，概念設計レベルでも作られ た構造を直ちに最終構造とするのではなく, 結果の評価 を行って 製品化に至る以前に誤り等を見つける外ない． 正しさを保証するために構造を評価するという考え方は 部品設計でも概念設計でも同樣である . しかし概念構造 の評価は, 構造の表現法においても, 構造を生成するこ とと評価をすることの時間関係においても部品設計のよ うな単純なものではない．このために情報技術として新

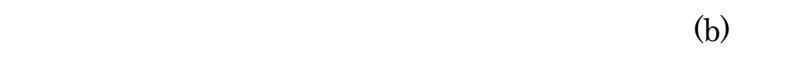
る.図 4 (b)で情報システム開発が作業ループの中に入ら ねばならないのがこれを表している．

現在の情報システム開発は対象のレベルで個別の問 題解決システムを人間の手で開発するものとしている.

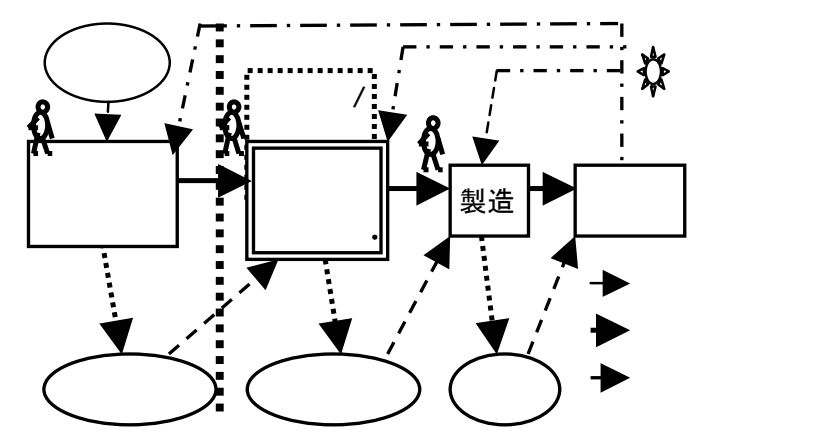

(a) 現在の開発方式

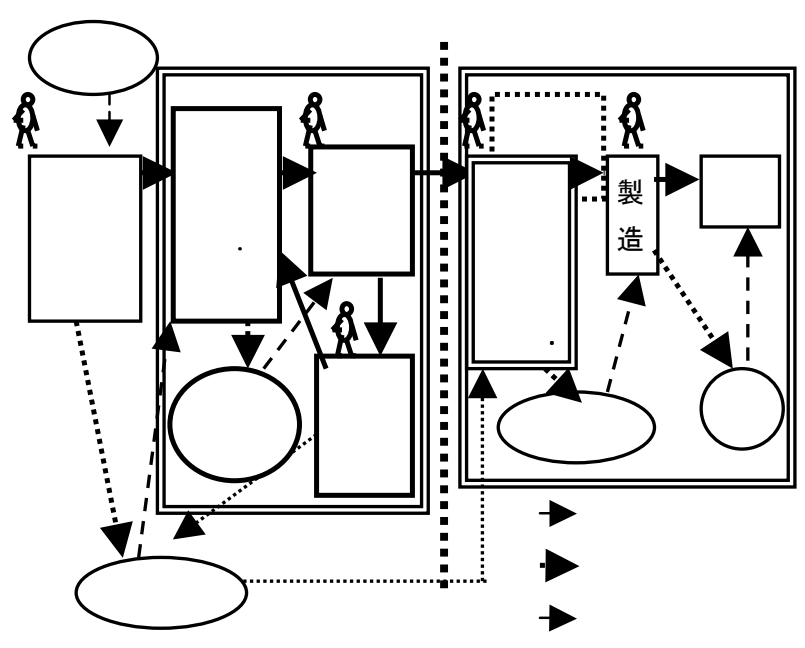

（b）望ましい開発方式

図 4 開発過程 
これでは図 5 のようにならざるを得ない . 分野の問題解 決者は必要が生じると情報の専門家に情報システム開発 を依頼せざるを得ず, 分野システムの開発に異分野の情 報技術者が入り込むことになる．この開発には時間か溎 かり，意思伝達の不正確のために正しい要求仕樣が作ら れない可能性もある.さらに仮説としての概念構造を変 える度にこのサイクルが必要になる.これは事実上実施 が困難でありこの過程は省略される，弚の結果が図 4

( a )である .

これを防ぐには分野システム開発のループに情報分 野の技術者が入らないで忟む方式を実現する外ない，光 れには図 6 の樣に情報システムを自動生成する方式とす る外ない . 情報技術者が行うのは対象のレベルのシステ ム開発ではなく，システムを生成するメタレベル技術の 開発である.この技術によって開発されたシステム自動 生成システムが分野の問題解決過程に含まれ，概念構造 を入力として受け取って必要な情報システムを生成し， これが開発に利用される.この方式なら問題ごとに人手 による新たなシステム開発は必要としない .この点は部 品設計のレベルでC A D / C A Eが使われる状況と類似 になる．CAD／CAEシステム開発を実際の問題解決 (設計) の最中に行うことはない，C A D / C A Eの場 合は分野か限定されているので, 問題範囲が予見され, 前もって必要な処理機能が定義されるので対象レベルの システムとして比較的困難なく開発されてきた . 問題が 予見できないときはこれが困難で, 問題が見えたとき直 ちにシステムを生成する方式とする外ない，問題が予見 可能か，予見困難であるかが，情報システムを対象レベ ルで開発可能か, メタレベル開発が必要であるかを分け ることになる .

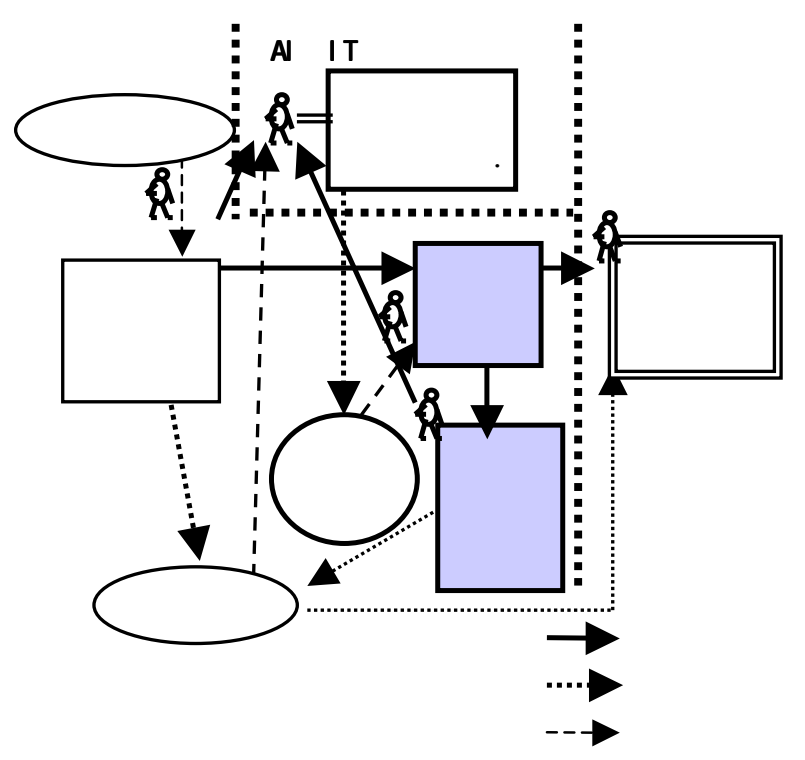

図5＼cjkstart現実の開発方式

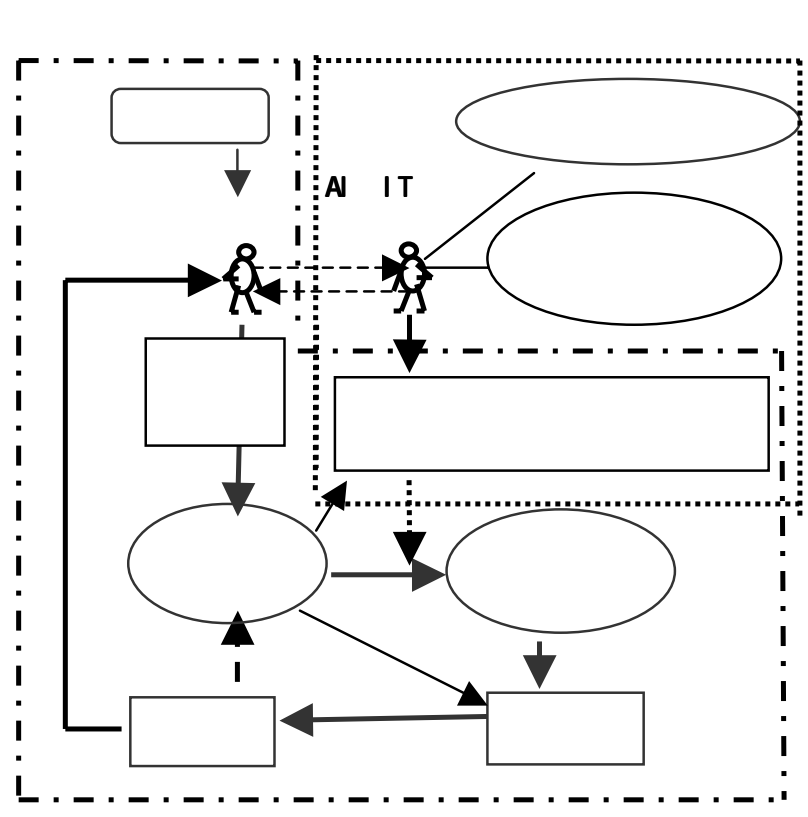

図 6 情報システム開発における情報技術者の役割

人間世界の問題は予見可能か予見不可能かによって 2 分される. 今日の情報技術は予見可能な問題にのみ利 用できるレベルである.このため多くの問題か情報技術 を適切に利用できないまま残されている．この範囲を力 バーする新しい情報技術の意義はきわめて大きい .

\section{4 支援システムの汎用性}

これまでは支援システム構造の柔軟性を強調するた めに開発を例として述べてきた . 開発の特徵は概念構造 を作り上げることであるが, 対象の構造がすでに存在し ている場合，例えば解析や診断などの場合でも対象の構 造にあわせて支援システムを構成する上記の原理は同じ である. 個々の支援システムに与えられる問題に応じて， 処理内容の異なるエージェント・システムが自律的に生 成される．あるいは光のような情報技術を開発すること が必要である.

また，これまで技術問題を中心に述べてきたが，問題 の本質は技術分野に限らず，政治・経済・産業・流通・ 環境・福祉など，広く人間の知的活動として未知の世界 に進む際に取られるほほ唯一の方法であり，分野によら ない一般的な方法である.技術問題を中心に述べてきた のは開発例が多数あり, 人間の発想から始まって具体的 なものに至る迄の過程の体系化がなされてきたので議論 の導入に便利であったからにすぎない 図 4 ( b) は技術分 野におけるこの過程を示しているが，このうち技術分野 に直接関わるのは縦の太い点線の右側の部分である . 左 側の部分は人間が構想を練る段階であり，目的か技術的 な製品の開発であるなしに関わらず行われる部分である． 上記の情報技術を開発するなら，乥れは人間の目標指向 のあらゆる活動を支援する極めて普遍的な技術になる． 
ただし情報技術を導入する以上, モデル化ができる範囲 の問題に限定される.

\section{3. 新情報技術実現の条件}

新情報技術の開発に先立ち，新支援システムへのニー ズをもう少し深く分析しておこう . キーとなる概念は

（1）世界のモデル (概念モデル) を作ること

（2）広い範囲で動く視点に対応する情報システム を生成する上で必要な知識

（３）動的な視点変化に対応して情報システムを実 現する自動システム生成

である .

\section{1 概念モデル}

技術開発支援の場合, 支援のための情報システムは概 念モデル構造に基づいて定義された . 谷の全体構造は, 概念構造要素に対応する作業単位ごとに定義されるエー ジェント・システムをビルデイング・ブロックとして形 成される . 各ビルデイング・ブロックは概念モデル構造 に従って相互関連され, 分散系として独立にかつ連携的 に動作する．この意味で概念モデルは中心的な役割を持 っている .この役割をより明確にし，実現方式に結びつ ける .

概念モデルに関しては古くはデータベースの3 階層 構造の一つである概念モデル, 最近は対象指向モデルな ど , これまでも樣々な提案や議論がなされてきた .これ らのモデルの議論は, 意図する役割に応じて異なってい る . データベースにおける概念モデルの代表例とも言え る ER モデルは主としてビジネス分野での活動をあるが ままに(静的に) 表現することを目指して開発された .こ れをどのように処理するかは別の問題であった . オブジ ェクト指向モデルはこれに比べると特定の処理系を実現 するための表現モデルである . 予見できない問題の処理 を可能にする新情報技術の開発と言う目標に対し，どの ようなモデルが相応しいか, 既存のモデル概念が利用で きるか否か，を知るにはモデルの満たすべき性質をより 詳細にしておかねばならない .

\section{§ 1 意図/問題表現としての概念モデル}

末知項を含む概念モデルが問題の表現であり，すべて 既知項となって矛盾の無い構造に至ったものは最終解を 表す. 問題解決は問題のモデルを処理して解モデルに変 換することである . 概念モデルのどの部分が未知項であ るかによって問題の表現, すなわち最初に人間が与える 初期概念モデルも解決の方法もまったく異なる . 概念モ デルは人間の意図あるいは問題の表現を容易にするもの でなければならない . 兴れには実問題において問題がい かに表現されるかを知らねばならない。
技術開発問題を例にとろう。前述したように，これは 構造自体が未知項であり，与えられる条件を満たす構造 を求める問題であった . 概念設計はこの問題解決のプロ セスである . 条件は一般には多くの機能・性能的要求で あった，例えば自動車について言えば，速度，加速度， 燃費, 発進・停止特性, 安全性, コス卜, 外観など, 多 くの条件を満たすことである．このように開発型問題解 決の定義は,「機能·性質に関する要求を満たす構造を見 いだす行為」であるから , 問題の表現としては構造を定 める上で必要なすべての機能・性能的要求を最初に与え ればよい. 問題表現はこれらの機能・性能要求を表す単 純な概念モデルですむように見える．

しかし実際にはこのように単純なものではない．多く の場合，条件を正しく与えること自体が容易ではない． すなわち人間自身が問題を正しく表現できない状況で問 題解決が開始されるからである . 開発によって , 目的を 達成する具体的な対象構造が見いだされたとしよう.こ れは多数の部品からなる構造である . 使われている部品 には光れ光れ固有の性質があり，光れらが最終的に対象 全体の機能に関わる. 従って, 求める構造は与えられた 条件も満たすが, 同時に, 設計過程で導入された部品を 通して, 与えられた要求には含まれていない樣々な(部 品の) 性質が (暗黙的に) 導入されたものになっている.

逆に，「これら暗黙的に導入されてきた機能・性質を 含めた全ての機能・性質がこの構造を特定している」と 言うことができ，この構造が正しい解であるなら問題解 決に乥れだけの情報が必要で, 最初から要求に含めるべ きものだったということになる .上記の゙もし構造を定 める上で必要なすべての機能・性能的要求が問題として 最初に与えられているなら'という条件は, 定型的な作 業手順を可能にするには前もってこれだけの情報を作っ ておくことが必要である, ということであり, どのよう な部品を使うかを含めて最初に解を見通していることに 外ならない. 解が見通されているなら問題解決をしなく て済むから，一般には光のようなことはない．一般に開 発目標に挙げられる機能・性能は必要最小限に留まり， これを満たす構造は必ずしも一つに限られず, 要求され た機能・性能は満たすが, 乥れ以外の機能・性質はすべ て異なるものの集まりである . 中には解として不適切な ものもある. すなわち問題定義が不十分であり，これが 普通といえる. 弚れら付随的な条件を開発の過程におい て順次対象に含めてゆくことが概念設計過程と言える .

現実はこれを機能・性能として (言語的に) 表現する 代わりに, 弚れを満たすと考えられる構造を直接書いて しまうことの方が人間にとって多くの場合容易である . この樣に人間が与える問題の定義を「機能・性能要求で 与える」ように固定することは人にとって制約になる． 機能・性能要求は通常は言語で表される．複数機能・性 能間の関連を含めて, 機能・性能への要求で問題をすべ て表現することは； 問題を言語で表現すること'である 
が, 文章化に固有の文脈を考慮しながら複雑な問題を文 章で表すことは容易ではなく，また正しさを直接評価す ることが困難である . 产のため人間の世界では, 機能・ 性能要求の言語表現に加え, 直接図 5 の樣に概念構造の 概案を作るとか, 弚の 1 変形である動作シナリオを作る 樣な方法の混用を許すことが行われる．すなわち，複雑 な問題を定義することが人間に取って第 1 に困難な仕事 であり，問題解決支援をするには，人間にとって容易な 問題定義を可能にするような支援から始めねばならない．

言語表現が困難なことは, 少なくとも問題解決におい ては人間－機械コミュニケーションを自然言語で行えば よいという安易な考え方が成り立たないことを示してい る。一方, 直接概念構造を表示し, 機能要求を弚こに個 別に記入する方式では, 全体の文脈に相当する機能要求 の関連付けが構造関係で間接的に乥して自動的に生成さ れ，機能要求間の関係も容易に理解される. 乥してこれ は問題ごとに異なるものではなく，すべての問題に共通 した表現形式なのである .

\section{§ 2 問題の定義に必要なすべての情報を定型 的に表現していること}

情報システムの自動生成を含め, 概念モデルの自動処 理は, まず基本となる概念構造表現を定型化し，表現の 枠組みを定めることが必要である . 定型化の条件は ,

（1） 光の枠組みに基づく処理が容易であること =単純であること

（2）定型化された範囲で対象の表現が可能なこと =記述力の高いこと

である この 2 条件は一般には排反的である たただし( 1 ) で定型化されることによって人間にとっても表現がしや すくなる面もある. また表現の枠組みが複雑になると， 記述力は増すが人間が使いこなす事が困難になる．これ を補うため，できるだけわかりやすいインターフェース が必要である.

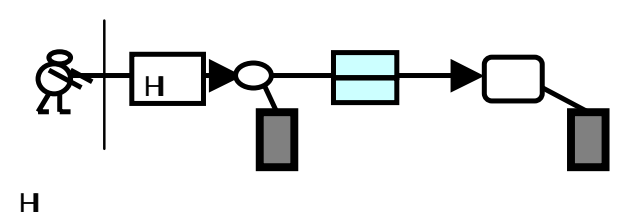

(a) 人間主体の要素

非人間主体と行為

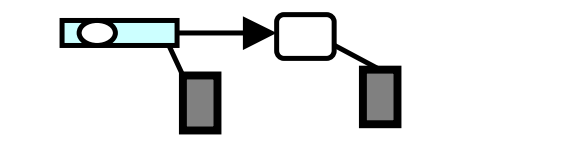

(b) 非人間主体の要素

図 7 多階層モデル構築要素
概念構造か階層的になる理由の一つに, 人間が一度に 可能な作業単位の大きさか制約されることがある.従っ てこれを明示すること，光のため，枠組みの中に作業を 行う主体と光の処理範囲の表現が無くてはならない．す なわち「行為主体 (人間) が，何 (対象) についてどの ような行為を行うか」を基本の単位とする必要がある。 これを「主体一行為一対象」三つ組みと表し,概念ユニッ トと呼ぶ . 図 7 にこれを示す. 行為の主体が必ずしも人 間である必要はない，概念構造内に自動化装置が組み込 まれる場合には，光の行為の主体は人間ではなく，これ とは別の非人間主体( コンピュータ等)である.概念構造 内では人間主体は図 7 の樣に人間エージェントである .

「主体一行為一対象」三つ組において，「主体」は行為主 体として構造の一部を形成する。「対象」は行為が光こに 及心範囲を示す．例えば行為が部品設計であるなら，対 象は部品を表す概念構造要素である、概念設計では人間 を含む下位の概念二ニット自体が対象の一部に含まれる． 三つ組内の「行為」は主体が対象に対して行う行為を表 すもので, 定型的言語表現として述語である .一般には 「主体」に複数の行為か割り当てられるこの時,「行為」 は光れ光れの異なる行為を表す述語の組である．

行為には少なくとも2 種有る.第1種行為は主体が対 象に対して行う行為，第 2 種行為は上位の概念構造要素 から下位の構造を定義してゆくための行為で, 図 7 (a) では光れ光れ行為 1 , 行為 2 と示されている.これらは

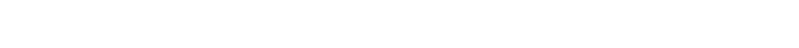
構造を評価する行為も含まれる．

主体, 対象は光れ光れ固有の属性や他の要素との関係 を持つ，例えば主体は名前等の属性や固有の性格を持つ． 弚れにも述語が用いられ，複数の記述の組である. 対象 に与えられる属性の中には, 機能や性能のように, 光の 対象を形成している構造によって定まるものがある．す でに述べたように，一般に「物」の構造として表される 対象 (例えば航空機) は光れを構成する部品（例えばエ ンジン, 翼等) の機能・性能と, 弚れら部品間および対 象一部品間の関係として定義される構造によって一意に 定まる.これを機能一構造関係と呼ぶ. 設計行為はこの 関係の制約内で所要の機能・性能を発揮する構造を見い だすと言う行為であり，乥れを，( i ) 目に見える構造を 作り，( ii ）光れを評価する，と言う形式に定型化したも

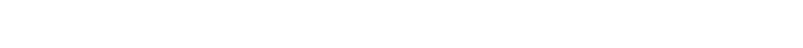
対象の性格を規定するものである . 行為についても性格 を規定する条件がある．これは行為内容の記述に対する 記述であり，メ夕記述である，一般に概念構造要素から 作られる概念構造において, 上位概念二ニットの第 2 種 行為は下位概念ユニットの行為を記述するメタ記述であ るから, 構造上, 行為の属性は上位要素の行為記述に含 まれ，これが行為間の上下関係を作る.主体についても 上位要素の主体と下位要素の主体間には上下関係があり， 権限の範囲が異なる等, 上下位主体の属性間の制約条件 
が作られる．これらもすべて述語として表現される．

対象に付いては, 同一の対象構造の上位要素, 下位要 素 (部品) の関係にある場合, 上記の機能一構造関係が 内在する .これは主体間の上下関係のように，任意に作 られるものではなく，機能一構造関係が満たされるよう に対象構造が作られねばならない .

概念モデルは図 7 の構造要素を組み合わせて作られ てゆく .このような概念モデルの形成方式を多階層モデ ルと呼ぶ . 概念構造の形成過程の一例を示したのが図 8 である．これは目標の機能・性能を満たす製品を設計す るため, 人間を含む概念構造を構成してゆく過程を想定 したもので, 設計の例を用いたのは, 概念モデルが問題 解決の進行に伴って動的に生成されるという難しさを持 つ問題だからである . 他の問題例えば解析では最初に概 念モデルが作られた後, 問題解決が始まる. 図 8 の例で は最上位のユーザは実際の作業はせず，下位構造を定義 する行為 (第 2 種行為) のみをもつ特殊なものとして表 されている.一般にはすべて標準的な 2 種の行為を持つ が, 図では煩杂隹になるため一部を除き単に行為とのみ表 している．ただし構造の末端要素は対象に対する行為の みに専念する. 従って行為1のみを持つ.

[1] 図 8 においてユーザは複杂隹な対象の設計を意図し， この実務を人間 A に委ねる場合を想定している. 炎の行 為(第 2 種行為)の内容は,

（ｉ）下位概念ユニットを作り，人間 A を下位概念ユニッ トの人間主体として割り当てる .

( ii ) 人間 Aの行為 1 を製品を設計する」と指示する .

( iii ) 設計される製品すなわち対象の満たすべき要求を 指定する .

である．人間主体は専門分野, 過去の経験, 性格等の属 性を持つ，（ｉ）の人間主体を割り当てる行為に際してこ れらを参照する .

上記の行為 2 の展開は知識として表現され，「行為指 示」のような名前が付けられる. 第 2 種行為を「行為指 示」と指定しても, この段階では要求として未処理項に なっている. 問題解決過程に入ると概念モデルの未処理 項が順次評価される.「行為指示」の場合, 上記知識が呼 び出され，この知識に基づいて実行される.

行為を明文化して表すことによってこれを要求とす る問題解決プロセスが明示的に行われて記録されること になり,開発中あるいは開発後のチェックが可能になる . 下位の主体への行為指示が人間間のコミュニケーション で行われる場合, 乥こに伝達エラーが入る可能性がある が , 上記の樣に明記することによりこれが避けられる .

[2] 上位概念ユニットの行為が実行されると下位概念 ユニットの行為が定まる.この例では実際の製品設計で ある.このようにして下位主体 A か指示された行為を末 処理項として持つ新たな問題表現が作られる.下位主体 A はこれを実行する. 設計者 $\mathrm{A}$ は要求された機能・性能 を持つ対象の構造を求める. 前述の, 「離島間の新しい乗
り物を設計する」場合のように，この要求機能を満たす 方式には樣々な可能性があり， A は目的の達成の概念構 造を作る、ただし機能が複杂隹なものは構造も複杂隹で, 概 念形成も多段に行われ，Aは午の第1段を行う. 例えば 上記の乗り物を水中翼船方式とし，光れが「船体」,「エ ンジン」,「水中翼」等から構成されるものとする．A は 目的とする機能・性能を満たすためにこれら各部(組み 立て) の機能・性能と, 弚れらの間の関係を定める . こ

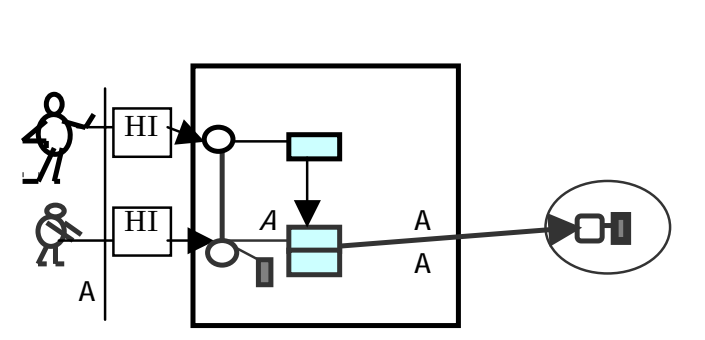

(a) モデル構築開始

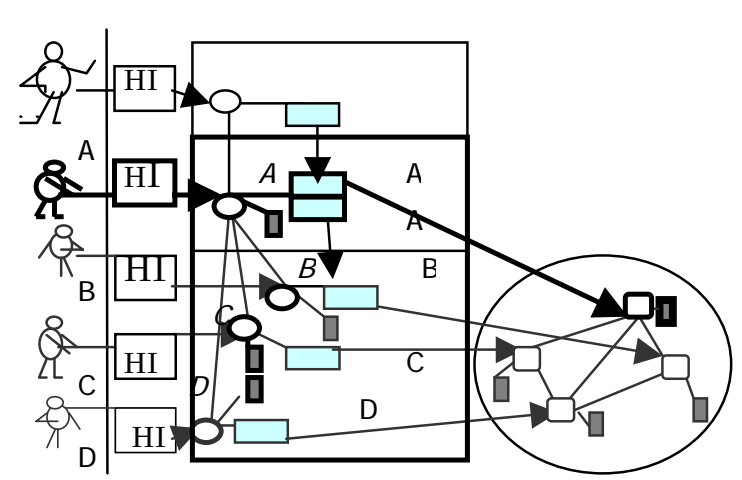

(b) モデル構築 (中間) [ ; 属性 ·

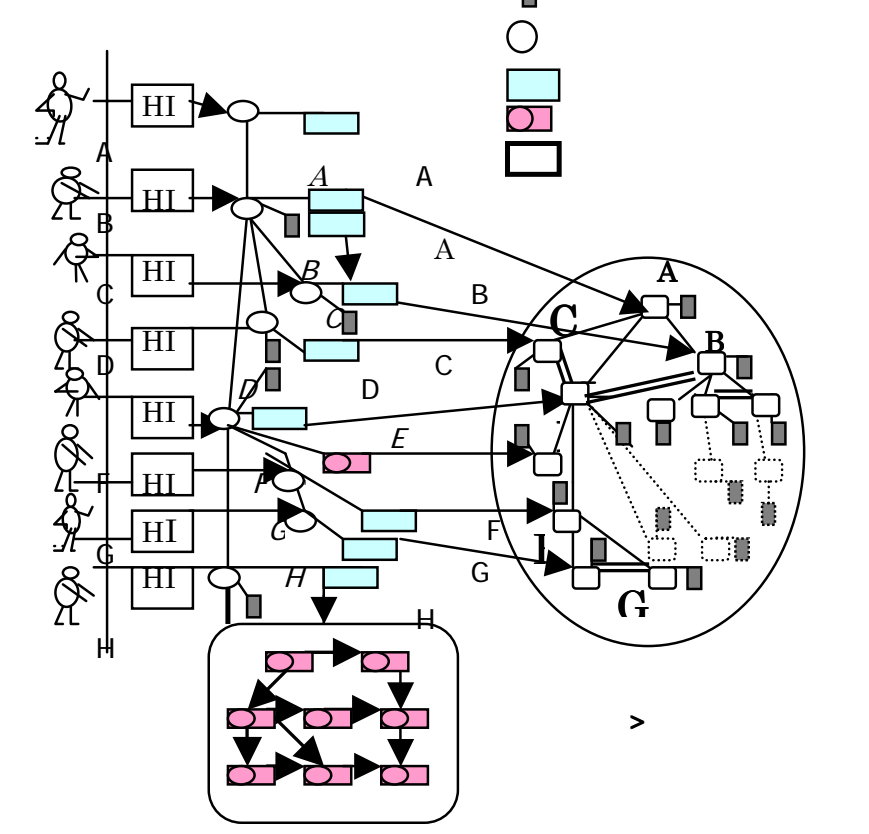

(c) モデル構築 (中間-続)

図 8 多階層モデル構築例 


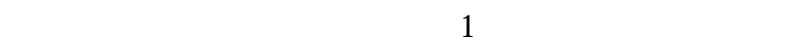
れ以後の設計を光れ光れの専門家に委ねることにし，下 位の概念ユニット B，C，D等を生成する．これはユ一 ザによってAが生成されたと同樣で，Aの第 2 種行為の 役割である。

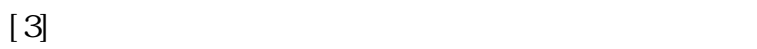
うに行為を行う．これは A の場合と同樣である. 図 13 はこのようにしてトップダウンに作られる概念構造を示 している.この過程で必ずしも人間主体を割り当てなく ても実現可能なものについては図 12 (b) の形式の非人 間主体の概念ユニットが用いられる .これは上位主体が 自動設計可能と判断した場合である[ OHS 96] .

\section{§ 3 行為の自動化}

上述したように下位主体を定義する際，光の行為仕樣 がすべて明確で, 機械的な処理が可能なものは非人間主 体を割り当て，自動処理とすることができる．さらに， ある範囲の下位行為がすべて非人間主体行為として定義 される場合，これらの構造関係から上位のマク口行為を 行為構造に展開することができる、構造内の行為が全て 自律的行為である場合，この上位行為自身が自律的行為 になる . 後述するように , この行為構造はプログラムに 変換が可能である .各行為は知識によって表現されるが， 产の解釈 (推論) 過程を記録して, 行為構造の実行系を 作り，手続きプログラムに変換することになる . 作られ るプログラムから見て, 行為構造の定義は仕樣の作成と 見ることができる

\section{$\S 4$ 従来モデルとの違い}

概念モデル図 8 は「主体一行為一対象」三つ組みを基 本要素とする点で特殊なものであるが, 従来の方式との 対応をつけておくことは本方式の特徵をあらわす上て効 果的であろう. 本概念モデルと概念的に最も近いのは データベースの概念モデル，例えば ER モデルである . しかし本概念モデルで重視するのはモデルの表現と同時 に光のモデルの解釈・自動処理を通してモデルの自動再 構築をする点にあり，これを可能にするための表現形式 への条件がある. ER モデルの記述力はこれまでに述べ た条件を表すのに十分ではなく，自動処理に関する議論 も未だ不十分である．ただし，概念的に類似のモデルは 相互変換の方式を見出すことができるから，相互利用の 可能性は探る価値はある .

一方，現実の例，特にモデル化か強く意識されてきた 技術開発の場合はどうであろうか? 現実の問題において は経験を通して表現が決められ，分野によってまちまち であるが, 多くは表面的な表現の違いであって，必要な 情報には共通点が多い．これまで用いてきた技術問題と の関連で言えば，製品モデルとか対象モデル等と呼ばれ る「開発対象のモデル」がある．これはかつて設計図と して 2 次元图面で表され，CAD 等の導入によって 3 次 元表現に変わっているが, 対象の構造部分は厳密に表現 されてきた .これは图 8 において対象モデルと示されて
いる部分に相当する .

図 8 では構造と共に機能・性能・属性が書き込まれて いるが, 通常はこの部分の表記は構造に直接関連する一 部 (表面粗さ等) を除き，別に作られる「設計書」等に 含まれる.設計書の表記を構造に結び付けて解釈・処理 をするのは人間である (关の際人間に判る表記の一部は 省略されてしまう）設計書は行為と属性等に関わる記述 で, 言語表現を必要とする部分である.これは图 8 のモ デルで行為の記述，属性等の記述に対応する．一方，開 発に関わる人間の構造を示す「組織図」が，主に管理目 的で作られる.これは图 8 の概念モデルで主体と光の関 係を示す部分である

このように图 8 の概念モデルに含まれる多くの部分が 現実に作られている．従来は人間主体で作業を行うこと を前提にしていたので，表現形式に制約は無く，また主 体，行為対象のモデルが关れ艺れ別個に作られていた . この表現から関連する部分を読み取り，計算を含む多く の処理を行うのは人間であった . 本方式は弚れを自動化 の範囲に含めるために，弚れらの関連を明示する三つ組 みを基本要素としている.

このように自動化のためには基本のモデル表現の枠 組みから变えることが必要である.なお, 图 8 は説明図 であって，実際にこれをどのように表現し記憶するか， すなわち物理モデルをどのようにするのか効率的である かは別途考えねばならない，従来の製品モデルと同樣， あるいは光れに変換可能な方式で対象モデルを表現する 樣に考えることも現存資源を利用する上で重要である . 重要なのは, 従来は別々に作られてきた情報同志が, 自 動処理可能な形で結び付けられることである .

\section{2 知識処理と知識ベース \\ $\S 1$ 大規模知識ベース}

変化する状況においては処理機能を動的に自動生成 する方式が必要であり，乥れにはデータとしての知識(背 景知識) を素材にして知識構造を自動的に構筑し，光れ を直接動作化するか，あるいはプログラムに変換するこ とが最も有力である.これにはまず動的な知識構筑と光 の処理が必要である.生成される処理系は, 視点が定ま つた時光れに関連する処理範囲を確実に含みかつ最小の ものであることか望ましい．この範囲を視野と呼ぼう． システムとしては視点変動に対応して, 関連する視野の 範囲全域をカバーする知識を準備することが必要である． これにはシステム内に大規模知識ベースを作り，光こか ら関連知識を検索する外ない . かつて人工知能分野で専 門家からの個人の知識收集は困難と言われ，光れを大規 模に収集するのは不可能という見方もある.しかしこれ は主に専門家の頭の中にある知識を言語化することの困 難であった．現実には，例えば技術開発支援のような分 野において要求されるのは既に言語化された大量の教科 書的な知識が, 多分野にわたって, 使いやすい形で存在 
することである .これらの知識は形式を定めておけば， 最初作成するときにマンパワーを要するが, 知識の収集 に技術的な困難は少ない. 予見の困難な問題解決を支援 する上で, 要求に関わる処理能力はいかなる形式であれ 不可欠であり，表現形式として知識を用いるとしたら大 規模知識ベースは不可欠である . 従って以下の議論にお いては大規模知識ベースの開発を前提とする .

\section{§ 2 視点設定}

個々の問題解決において必要最小限のシステムを生 成するには，視点と視野を正しく同定せねばならない． 人間同士の会話では視野は文脈から見いだされるが, 必 ずしも正確なものを要しない.一方, 実問題解決では正 しい視点の設定が重要である．

実問題には異なった解決方法論を必要とする樣々な 種類のものがある . 同一の方法論で処理される問題のク ラスを同じ型であると言う. 実問題には樣々な型がある . 例えば, 設計, 診断, 制御, 計画, 等は固有の方法論を 必要とするので異なる型を示す . 問題型ごとに , 谷の問 題解決の方法論を知識として表現し, 問題に応じて光れ を呼び出すことによって, 多樣な型の問題解決が可能に なる*1.

基本の型の問題解決方法論が準備されていれば, 多種 の問題型を含む複雑な問題の解決法は個々の方法論を組 み合わせることによって問題毎に生成される.図 9 に代 表的な型の例を示す. 設計型, 診断型に含まれている評 価は解析型を含む．これらは複合型である．

基本の型は同じでも，対象によって問題解決の具体的な 方法の細部が異なる場合がある . 例えば , 同じ設計であ っても，機械を対象とする設計と，プログラム設計では 細部で方法が異なる . すなわち個々の問題型は平板的で はなく，分野によって構造化される．

方法論は対象に関する特定の処理要素の, 一定の構造 で表される.設計についていえば初期モデル構築, モデ ル計算, モデル評価, モデル修正を一定の手順で構造化 したものである .これら各処理が知識に基づいてなされ るのが知識処理方式であり, 光れ光れ初期モデル構築知 識, モデル計算知識, モデル評価知識, モデル修正知識 が使われる．このように知識を型と分野に応じて光こで 使われるものに限定して準備すれば, 視点 (作業内容) に応じて視野が見出される.すなわち視野同定は視点を キーとして大規模知識ベースから 型× 分野' で定まる 範囲の知識を検索することによって達成される .これに は大規模知識ベース享のものをこれに適した形式で構造 化する必要がある .

*1 未知の型の新しい問題が生じたときは, 弚の解決の 方法論を新しく見出さねば成らない．これはあらゆる行 為の中で最も創造的な仕事であり，人間が行う外ない． 方法論がない限り，いかに高度な情報技術を用いても自 律的問題解決は不可能である[OHS 01]. (a) 解析型

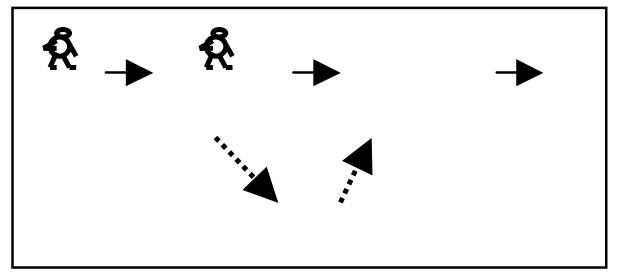

(b) 設計型

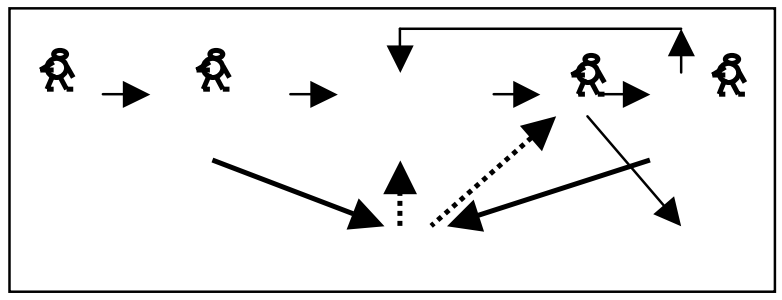

(c) 診断型

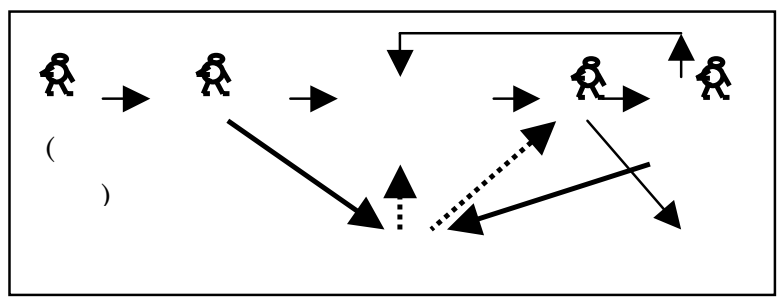

図 9 問題型と炎の問題解決構造 (問題解決方法論)

\section{§3 知識の構造化}

知識ベースは方法論知識ベースと領域知識ベースか ら成り, 問題型, 分野の両方で構造化される. 図 9 から 判るように方法論の知識は分野知識の使い方を示すメタ 知識であり，分野知識が方法論知識の下で構造化される .

個々の方法論を形成する処理要素 (設計問題の例では モデル構築, モデル計算, モデル修正など）の種類は有 限で, 異なる方法論自体の種類も有限であるから, 全方 法論を通して異なる処理要素の種類全体も有限である . そこでまず知識を処理要素の種類によって分類する．例 えばモデル構築の知識群, モデル計算知識群, モデル修 正知識群などである.さらに, 各処理要素の知識, 例え ばモデル計算知識, は分野毎に異なるから, 光れをさら に領域によって分類する.このようにして領域知識べー スの (操作×領域) によるクラスタが作られ, 弚れが方 法論知識と組み合わされる. 図 10 はこの構造を示す.

問題型と問題分野が特定されると，光れをキーとして， この構造化された知識ベースから所要知識が検索される . なお問題型, 問題分野とも, 平板な分類である必要は なく, 階層的に細分化される . 例えば, 設計と言う問題 型は, 標準的な設計の方法論のみでなく，光の変形版が 分野に固有の設計方法として作られる可能性がある. 前 述したように, 設計と言う枠組みの中で, 機械を対象と するものとプログラムのように情報を対象とするもので は詳細が異なる.従って問題型を細分する.例えば図 11 


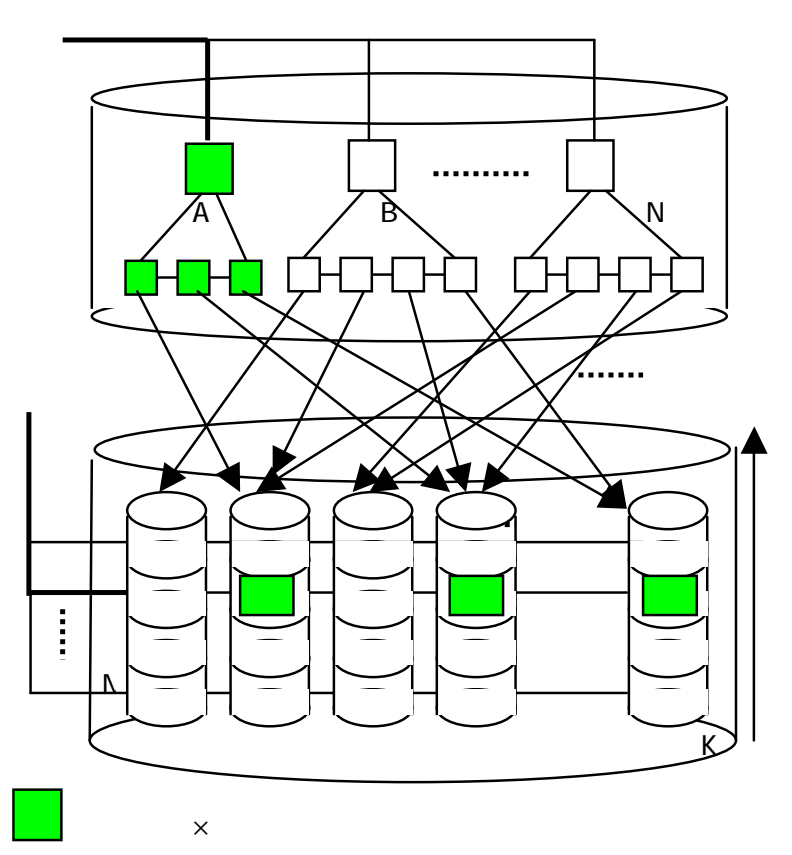

図 10 知識検索による問題向き知識構造の生成

で機械設計の方法論である設計 1 型 , プログラム設計方 法論の設計 2 型のように細分し，異なる名前を与える． 同じ機械に関する設計 1 型でも, 分野によっては領域知 識の特徵を活かした方法論の表現を作ったり，「A 氏の 設計方法論」のように，個人の方式が作られても良い． これらは標準型か細分化された下位問題型として定義さ れる.細分化は分野についても同樣に行われる.

これら構造の作り方に基準があるわけではなく，また 動的なものであるが，この構造の作り方に応じて知識 ベース構造が作られ，また後述するように，利用者が意 図を表現する際にこの構造を用いるので，光れらを考慮 して作成することになる .この構造の作り方が, システ ムの能力に関わってくる[OHS 01b] .

图 11 は概念の構造として，オントロジーの一種であ る.図11(a) はタスク・オントロジーに, 図11(b) はドメ イン・オントロジーに対応する.この構造で知識ベース の構築には多くのマンパワーを要するが, 一度作られた ものの共用性は高い[MIZ 99 ,YAT 99] .この枠組みと同 時に，ユーザがシステムを使いながら知識を保存して行 くような方式を準備することが重要である．

以上の処理によって生成されるものは, 知識と推論に よって解を自律的に見いだす情報システム，すなわち， かつてのエキスパート・システムと類似のものである . 言い換えれば，エキスパート・システムはこれまで述べ てきた前処理部分は全て人間に任せた上で成り立つシス テムであった . 問題解決において困難なのはここまで問 題を整理し絞り込むことである.かつてのエキスパー 卜・システムでは, 弚れ使えるようにするために, 問題 解決の本質的な部分はほとんど人間が行うことが前提で

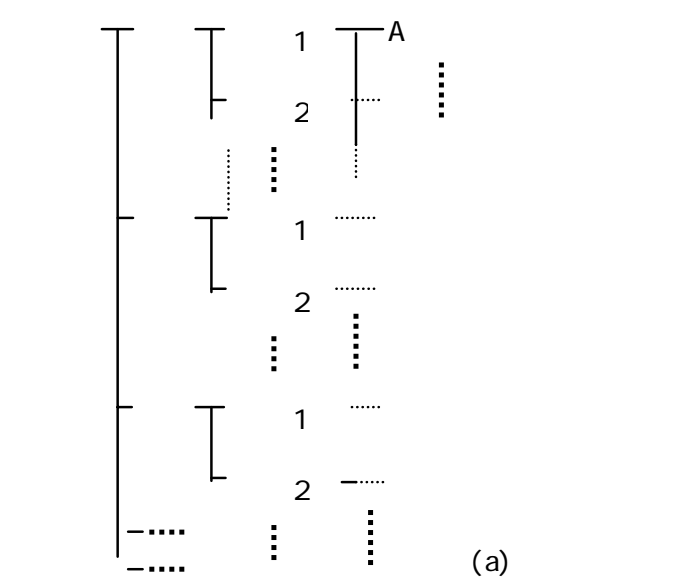

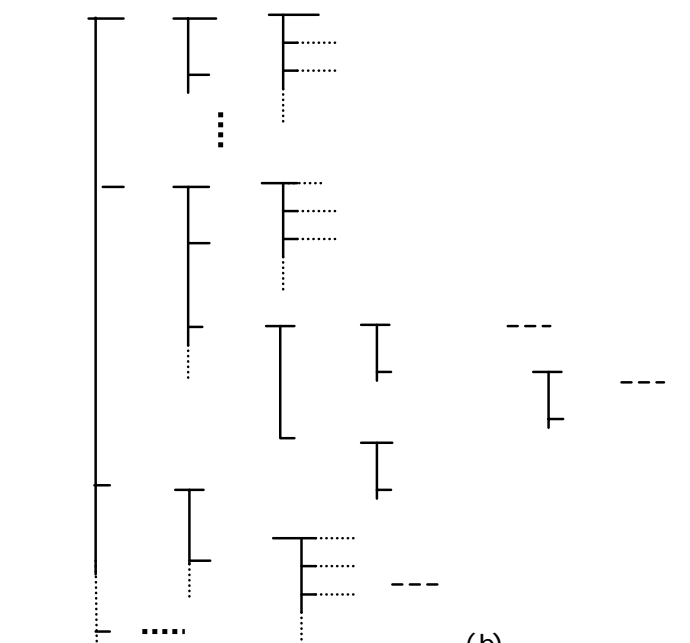

- …... (b) 問題領域階層

図11問題型と領域の階層

あり,エキスパート・システムガ扱えるのは狭い範囲の， トイ・プロブレムに近いもののみであると批判された理 由がここにある .

\section{3 情報システムの自動生成}

情報システムを生成することは，情報システム自身の システム設計と乥れを実現するソフトウエアを自動生成 することであり，いずれも極めて困難なこととされてき た . 後者について, 従来のソフトウエア方式では目的と するシステムを，手続き的プログラムを中心に表現する ことであるが，これは問題が事前に細部まで詳細に記述 されて始めて可能になる.予見されない問題はこの条件 に本質的に反する . 無理なコンピュータ化は人間の発想 を制約する．これに対処する方式が, 問題の表現である 概念モデルに合わせて情報システムを生成する方法であ る.これを適応的ビルデイング.ブロック方式と呼ぶ .

\section{§1 適応的ビルデイング・ブロック方式}

問題を概念モデルによって表現し，概念構造内の既知 部分から始めて段階的に未知の部分の処理を進めながら 
問題を解決するのが，事前に予見できない場合を含めた 幅広い問題に対応する問題解決方式である . 全体として は大きな概念から始めて順次細部の概念形成が行われる 人間はこのようなトップダウンの作り方を基本にし ながら, 問題に応じて, 内部の詳細に立ち入る前に, 形 態的な判断, 明文化し難い、経験, 他の問題とのアナロジー などを用い, 局所的な Breadth-First のアプローチを取 って概念構造を作る. Breadth-First と言っても一律に レベルを合わせるというものではなく, 状況に応じて柔 軟に深さと幅の変化を許しながら仮の概念構造を作るの が人間の優れた方法である .ここでは問題形成と問題解 決が適応的に組み合わされている.この方式によって各 段の概念構造の作成がフィージブルな範囲に収まる．

このような人間の柔軟な発想を許しながら乥こに支 援システムを導入する. 弚の役割は「各段階で仮の概念 構造の評価を行って試行錯誤を可能にしながら構造の詳 細決定を支援する」ことである．支援システムは概念モ デルに合わせて生成されるが, 一回に生成できるのは多 段に行われる概念形成の1段の処理を支援するサブ情報 システムである . 開発の場合のように, 上位の構造は既 に定まっているが下位は基本構造は定まっていない状況 にも対応せねばならないからである．従って情報システ ム全体はサブ情報システムが概念構造に対応して生成さ れ，相互に関連づけられるマルチェージェント型のシス テムとなる $44,5,6]$. これを適応的ビルデイング・ブ ロック方式と呼ぶ．

\section{§ 2 適応的ビルデイング・ブロック方式の定義}

ビルデイング・ブロック方式の基本は，

(1) 概念ユニットに単一の枠組みのビルデイング・ブ ロックを対応させることにより，全概念構造に対応する 情報システムの構造を作る，

(2) 実行時には光れらビルデイング・ブロックが構造 内の要求に応じて独自の動作をするように内容の自動定 義をする，

\section{ことにある}

ビルデイング・ブロックの枠組みは全て共通でありな がら，実行時には各ブロックが概念構造内で置かれた位 置に応じて異なる内容の処理を行うという条件を満たす ために知識処理を基本とする . 宣言的な表現に基づく知 識処理の方式は, 知識を用い, 光の組み合わせを作りな がら推論を行うことにより，前提条件からゴールまでの 道を自律的に見出すので, 準備された知識の範囲内で 樣々な状況に対応することが出来る、知識処理を構成す る枠組みは，知識を蓄える知識ベースと，処理を行う推 論機構であり，すべてのビルデイング・ブロックについ て同一である.知識自身は推論の処理対象になるデータ であるが，このデータを入れ替えればシステムは全く異 なる動作をする . 知識処理のこの特徵を活かす .

もし十分な知識量があれば広い範囲の問題に対応す るから，原理的には単一のビルデイング・ブロックで全
てすませることが出来るが，知識量か増すと組み合わせ 爆発が生じる . 個々の問題に対して利用する知識は全体 の一部であるから，実用性を確保するため，各ビルデイ ング・ブロックの実行時の知識を必要最小範囲に制限す る方法が , 視野に応じた問題向きの知識範囲を同定する のが前述した方法だった . 各ビルデイング・ブロックは 「視野に応じて問題向き知識ベースから知識を選び推論 を行う」,と言う同じ動作を行い,知識内容によって異な る処理が行われるようになる. 共用知識ベースは大規模 知識ベース管理システムで管理される

概念構造は末端の，対象の処理に専念する個別問題 (例えば部品設計) と，光れより上位にあって，下位の 要素の処理結果を組み合わせて統合化する統合問題から 形成されているが(図 3)，知識処理の下では使われる知識 が異なるのみで, 個別問題解決も統合問題解決も構造的 な相違はなく，ビルデイング・ブロックの概念は光のど ちらもカバーする . 個別問題解決が統合問題解決と違う 点は問題を展開して下位ブロックに送る部分が無いこと， すなわち概念モデル内で第 2 種行為か指定されないこと のみである .

各ビルデイング・ブロックは共用知識ベースに必要な 知識の供給を依頼し, 知識ベース管理システムは要求さ れた知識を検索し，供給するが，大規模知識ベースと言 えども多樣な個別問題解決に必要な知識を全て自システ ム内に共用知識べースとして準備することは非効率で， Web サービスのような方式を出来る限り利用し, 他所に ある機能を有効に使う方式が必要になろう [PAO $01 ， 11]$. これも知識ベース管理システムの役割である.

個々のビルデイング・ブロックは概念モデル構造内で 役割が定まるが, 弚の機能を定義するのは, 上位処理ブ ロックあるいは人間から当該ブロックに与えられる部分 問題である . 問題はモデルの一部として表されているか ら，ビルデイング・ブロック間で問題および解として受 け渡されるのはモデルの一部である。

\section{§ 3 ビルデイング・ブロックの構成}

图 12 にビルデイング・ブロックの枠組みを示す . こ れは (a) 上位ブロックあるいは直接人間から与えられる 問題すなわち行為内容と処理対象を受け取る，(b) 問題 に応じて必要な知識を外部の大規模知識ベースを検索し て取り込む，(c) 固有の知識ベースを形成する，(d) こ れに基づいて問題解決を行う，基本部分を有する．末端 概念二ニットに対応するものはここで部分問題の解が求 まる. 光れ以外の概念二ニットの場合，(e) 対象を要素 に展開し, (f) 各要素に対応する新たな下位ビルデイン グ・ブロックを生成し（枠組みを表わすテンプレートを コピーし), 個々の対象要素と产の処理要求を要求行為と して下位のビルデイング・ブロックに送る．また（g)下 位ビルデイング・ブロックから返送されてきた解を用い て問題解決を続行してこのビルデイング・ブロックの解 を生成し，(h) 結果を上位ブロックに返す。これに 


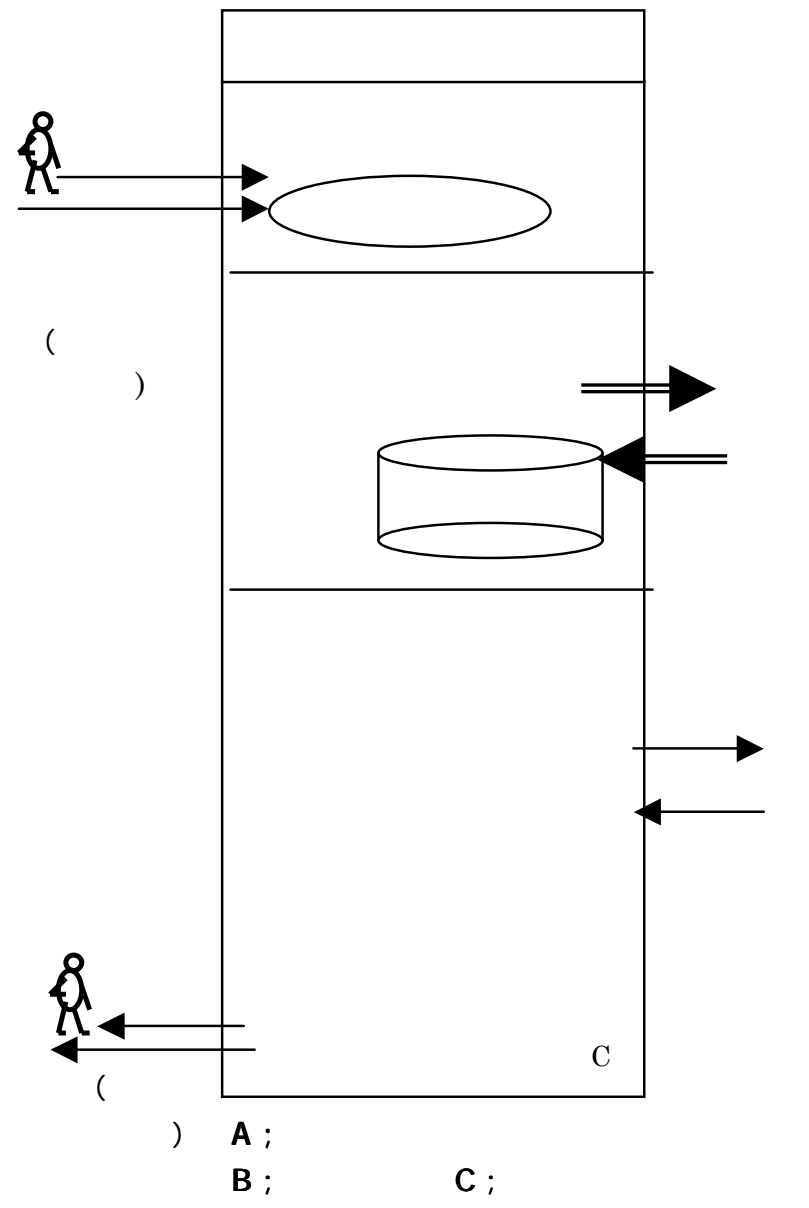

図 12 ビルデイング・ブロックの機能構成

よって，個々の概念ユニットごとに問題は全て異なるが， 必要な時点で問題を生成し，解を求めることができる．

\section{4. 主要関連課題}

以上，予見できない問題の解決を支援する，という課 題を実現するための基本課題を挙げ，解決のためのアプ ローチを述べた . 実際にはこの他に実用上どうしても避 けられない問題がある 新情報技術としては Web を介し た知識の収集, 発見, 知識獲得, など多数の課題がある が, これらは問題としては広く理解され, 多くの研究が なされているのでここで改めて取り上げることはしない． 本稿の課題にとりわけ関連の強いものとしてここでは

(1) 異種問題解決システムの統合

(2) システムの評価

(3) 自動プログラム生成

を挙げる．乥の理由と方式は以下の通りである．

\section{1 異種問題解決システムの統合}

大規模技術開発のように多分野にわたる問題開発で は対象に対して多樣な処理が必要である. 同一設計方針 の下で開発されるビルデイング・ブロック同士の統合は 特に問題ないが, 全く異なるパラダイムの下で開発され た既存のシステムを機能的に統合し，協調的に問題解決 に利用することは今後非常に重要になる，例えば，技術 問題では強度解析システム, 流体解析システム, 熱解析 システムなど既存処理システムが多数ある.多くの場合， これら処理システムは手続き的プログラムとして実現さ れていて, 弚の基本になっている問題のモデル表現も独 自のものを用いている.一般的に任意に開発される処理 システムは前提とする対象のモデルの表現が統一されて いない．これらの統合的利用には固有の難しさがある .

今日 , 遠隔のシステムを Web を通して利用できるよう にする Web サービスが実用化されようとしているが， 一般に処理系を開発する際に用いたモデルの表現と，利 用する側で用いられるモデルが異なると，この処理系は， 仮にWeb を通して入手は可能であっても，直接利用する ことはできず，モデルを共通化する技術が必要である． すなわち 3 章で述べた問題解決システムとは独立に開発 された既存システムを, 問題解決システムと協調的に利 用可能にする技術が必要である.

これはモデルに関するオントロジー問題であり，未だ 一般的解決方式はない．また協調方式に関しては，外部 の処理系を自システムに取り込んで目的に合わせた大き な処理系に構造化するほか, 外部処理系を持つサイトに 問題を送って処理を依頼し，処理結果を受け取る方式を 考慮する必要がある .これは外部の処理システム自体が 非常に大きい場合, 特に光の外部システムが独自のハー ドウエア，例えば外部情報を検知して処理を行うための センサーを用いるような場合に不可欠である。

筆者らは, 上記の樣に外部システムを機能的に問題解 決過程に役立てる方式を実現するものとして，概念モデ ルの解釈過程で上位ブロックが下位のユニットの問題解 決を外部システムに依頼する実験を行った . 概念モデル の中の処理依頼する部分をXML(Extensible Mark-up Language)によって形式的に共通化し，外部システムに 送る．ただしモデルに関するオントロジーの一般的変換 方式は実現しておらず，外部システムも概念モデルの共 通の解釈が可能なものとして, 送られたモデルの XM 表 現を自己のシステム内の固有モデルに再変換して処理を 行う .すなわち任意の外部システムと結合できるわけで はなく，予めモデルの共通解釈を与えておいたもののみ と結合が可能になる.一つの事例として, 人工衛星の自 律的故障診断システムを, 統合問題解決に組み込む方式 の実験を行い統合の可能性を実証した . 今後, モデルの オントロジー問題を解決する技術の開発が重要になる. 


\section{2 システムの評価}

図 8 においてユーザは単に下位の主体 $\mathrm{A}$ を割り当て， 仕事をさせることのみ示されたが, 実際には概念形成の 責任者としてユーザの最大の仕事が全体の概念構造の評 価である .これが図 6 に示されたモデル評価である . 評 価は解析に基づいて概念モデルの正当性を判定する行為 であり, 図 $9(a)$ 光のものである. 評価は人間が直接指定 する外，図 9の (b)，(c) のように他の行為型に含ま れる場合もある .

\section{§ 1 シミュレーション構造の生成}

評価自体が一つの行為であり，記述されてモデルに含 まれる . 評価対象は同じ概念モデルの一部である . この 範囲は評価される対象の側面と評価行為の表現内に含ま れる対象範囲によって定まる. 評価行為はこの範囲内の 対象の性質・機能と光れらの関係から上位対象の性質 · 機能を求めること, あるいは範囲内の下位対象が主体と なって行う諸行為のうち, 評価要求に関連するものが実 行されたときの結果の推定である . 評価行為の実行は内 容に応じて解析あるいはシミュレーションを行うことで ある・より具体的には評価行為を表す知識があり, 解析 方法あるいはシミュレーション方法が表現されている . 評価実行は評価行為の表現に基づいてこの知識を呼び出 して推論処理を行うことである.解析の場合 , 解析手順 が知識として表現される.一方, シミュレーションの方 法は評価目的に応じて多樣である.しかしシミュレーシ ヨンにおいて全体の動作の管理を行う部分には共通性が ある 例えば有る行為の推移を時間的に追ってゆく場合， 時間のインターバル, 繰り返し回数などをパラメータと する基本構造を作り, 兴の中に個別の下位行為を埋め込 んでゆく形式で全体のシミュレーションが可能になる問 題は多い . この樣なパターン化のできるものはこれ以外 にもあり，これらを知識化しておくことにより，モデル に基づくシミュレーションが自律的に行えるようになる．

異なる評価行為（例えばシミュレーション）は異なる 行為名を持ち, 弚の各々についてシミュレーション方法 を表す知識が準備される.これら評価行為は特定の問題 型として図 11 ( a ) の型構造内の解析型の一つとして含 まれ, 人間が随時指定することができるし, 設計, 診断 のような他の型の行為に含まれ, 弚の中で自動的に呼び 出されることもある．

シミュレーションを行うにはとの準備が必要であり， これは光れ光れの評価目的に応じて評価 (解析) 知識に 含まれる．例としてある建物を設計するために内部の群 集の動きを分析する問題を考えよう．この概念モデルは 主体として解析者と解析行為を持つ上位ユニットと, 個 人を主体とし, 状況に応じて一定の行動パターンに従う 行為を持つ多数の下位二ニットによって形成される群集 からなる . 上位主体は解析結果から建物の評価を行うの で, まず解析を行う.この解析行為は,

(1)シミュレーションの対象範囲を定める
(2)シミュレーションの構造を作る ，

(3)この構造の下て対象範囲内の主体の行為を実行し, 光 の記録を取る ,

(4)終了を判定する

というもので, (2)の「シミュレーションの構造を作る」

がこのシミュレーションの目的に直接関わる部分である .

これは

(2) - 1 微小時間間隔と試行回数を定める

(2) - 2 (3)の下位主体行為を微小時間間隔だけ実行させ る構造を作る

(2) - 3 終了判定部分を上記構造に含める

からなる.(1)は指定した建物内に居る下位主体の集合を 同定すること，(3はこの全ての主体について行為を実行 すること，(4)は試行回数か設定值に達したか否かを判定 すること，である.これらを知識の形に表現し，微小時 間間隔や試行回数を人間か設定できるようにして状況に 応じたシミュレーションが行われる．

これは一つの例であるが, 動作系の時間変化を調べる 一般手法であり，広い適用範囲を持つ.これについては 単純な問題について実験を行って実証の可能性を確認し ている.このほか動作の基本か時間の代わりに空間変数 であるもの, 乥れも 2 次元空間, 3 次元空間など, 異な る型のシミュレーション行為が作られる.これらのシミ ユレーション基本構造と, 兴の対象であるモデル表現を 組み合わせることにより，多樣な評価が可能になる .

評価はモデルの整合性を確かめることであり，正否判 定ですむ簡単な場合から，定量的評価が必要なものまで ある 後者が前者も含むと言う意味でより一般的なので， 弚れが可能な方式としておかねばならない，モデル内の 属性や行為のように述語で表される部分に, 乥れが正し く達成される尺度 (正当率) が含まれ，構造全体の表現 か整合的になるようにこれら各行為等の正当率を定める． 従って評価とは形式的には正当率を含めてモデル表現を 整合的にする行為である。

\section{$\S 2$ 人間の評価}

人間の行為は誤りが多いため, 人間を含む問題解決に 際しては人間を含む評価方式を定義せねばならない．人 間の誤りの結果は行為の内容によって異なる . 例えば図 9 にいくつかの問題型に対する方法論が人間を含む形で 与えられているが, 設計におけるモデル修正行為に入り 込む人間の誤りは，この方法論の試行錯誤ループに含ま れる評価行為によって次のサイクルで自律的に見いださ れる構造になっているので比較的影響が少ない．しかし 最終的な出口になる結果の評価部分にいる人間の判断誤 りは修正される機会がなく, 直接結果の正当性に影響す る. 従って行為の正当性評価には, 乥の人間の専門分野 と応用分野のマッチングの程度を調べるなど, 人間の能 力評価を含め, 誤り率として表す必要がある .

以上は問題解決で生じる誤りであるが, 概念構造の生 成時に下位の問題解決ユニットの行為を定義する際の誤 
りがあることは 3.1節で述べた通りである . 人間同士の 下位行為の定義は，口頭で行う場合，メモを渡す場合， 正式に定式化された命令書を用いる場合，など樣々であ る. 前 2 者の場合，誤りが生じる確立は高い . これを定 式化することにより誤りを減少することができる．

\section{3 自動プログラム生成 § 1 行為構造としてのプログラム}

関連技術として考慮せねばならないもう一つの大き な課題が応用プログラム生成である．これまで述べてき た方式は概念モデルによって人間が問題を定義し，情報 システムは光れを解䣋し，未処理部分があれば光れを実 行して概念モデルを問題表現から解表現に変換する, と 言うものであった . モデルの構成要素は主体 - 行為 - 対 象の三つ組みであり，この各部分が末処理部分になり得 る．もし主体が非人間主体であるとき，行為は自動処理 可能なものであり，情報システムは乥れを実行する .こ のような行為が同一構造内に複数存在するとき, 兰の全 体は上位主体が行うべき行為か下位のユニットの行為か ら構造化されたマクロ行為である. 行為は知識として表 現されるから，行為構造は知識構造であり，この実行は 推論による知識の解釈過程になる.

これによって予見できない問題解決の基本構造はで きているし, 概念モデルの自動処理部分の構造が動的に 生成されるので, 開発過程において仮説の対象のシミュ レーションをモデル構造に応じて実行し，結果によって 直ちに仮説を変更するような開発プロセスを実現できる 大きな利点を持つ 問題は実用性にある 特にシミュレー ションに関しては同一の処理を多数回実行する必要があ り，処理時間が最大のネックになる.これを解消するに は生成された行為構造を直接実行する代わりに，これを 手続き化する必要がある．ここに自動プログラム生成の 必要性があり，しかも実用面では重要な課題になる。

以下ではこの過程におけるプログラム生成を考慮す る.これは，(1) 小行為から大きな行為を組み立てるこ と，言い換えれば行為の構造を作ること，(2) これをコ ンピュータ用言語で表現する, というメタ行為である。 プログラム対象とされる行為は非人間主体を持つもの， すなわち機械的に実行される行為である．プログラミン グ行為の主体が人間なら, 人による通常のプログラミン グであり，非人間主体なら自動プログラミングになる 現在のプログラム開発過程に対応づけると，(1) は要 求・仕樣の作成，(2) はコーデイングに対応する.手続 き的なプログラムは要求・仕樣か確定しなければ作れな いが, 要求が定まり, 仕樣が正しく作られるなら, 今日 のソフトウエア工学の技術の下で作られるプログラムに 大きな誤りは少ない . 従って, 今日 , プログラム開発で 問題なのは上流過程と呼ばれている要求・仕樣作成の部 分すなわち (1) の部分と, この部分とインプリメント
である(2)との間のギャップにあり[WAY94 „MUR01] ， この一つの原因は応用分野の問題解決が不十分のため応 用分野における情報システムの役割が容易に確定できな いことにある.すなわち，これは一般問題解決の上流過 程と全く同じ問題である . 行為構造は応用分野に依存す るから，一般の問題解決と同樣，この作成は分野の専門 家に任せるのが合理的である .

多階層モデルでは行為構造は述語表現の階層構造で ある.上位の行為の実行は下位の行為構造を実行するこ とであり，光の結果を受けて弚れ自身の解とする.この ため構造の末端は実行可能な行為でなければならない . 行為構造を作るまで, すなわち問題解決をする部分は知 識処理による方式を用い, 結果としての行為構造を手続 き的プログラムに自動変換することが合理的な方法であ り，状況によっては不可欠である[OHS 98，OHS 99， HEY 02] .

最近モデルをベースにしたソフトウェア開発の方式 が注目されている、例えば[IPJ 04]に光の特集が行われ ている.これらはプログラムの生産性を重視しており， この基本的な考え方は，まず対象の注目する(プログラム 化しようとする)側面をモデリング手法を用いて表現し， 弚れからプログラムを生成するものである.しかしモデ ルの作成をプログラマあるいは情報システムの技術者が 作成するため，応用分野の理解は必ずしも十分でない場 合が予想され，モデル自体の正当性をいかに保証するか が大きな問題になる .

上述の方式もソフトウェア開発という観点から言え ばその一種という見方もできるが，モデルを応用分野の 専門家が作るという点で本質的に異なる立場にたつ．し かし当然共通点も多いので，今後相互の利用を検討する ことが必要である.

\section{§ 2 プログラム開発の特殊性}

プログラム生成は文脈依存性の少ない述語を要素と するこの行為構造全体を文脈依存性の強い手続き的表現 に変換することである .この中間構造として階層構造の 各階層で同一レベル内の横の関連を変数の関係によって グラフ構造として明示的に示すものが作られる .上位の 行為の入力- 出力関係は下位の行為構造(グラフ)の入出 力関係である (図 13).

プログラムも人工的な製品であるから，行為構造を見 出す問題は部品から対象構造を作る一般の設計問題に類 似である . しかし開発対象が行為の構造である点が一般 製品の設計・開発と異なる．弚の特異性の為に現実には ソフトウエア設計は物の設計問題と異質の性質を持ち, 固有の方法論が必要になる . 従って固有の問題型を与え るのが良い . 相違点として以下の 2 点を挙げる .

[1] 一般の設計はトップダウンに行われるが, 弚れは 第1に, 対象に関する多くの知見があり, 要求された機 能を持つ対象構造を作る際に, 無作為に構造を作って評 価するよりも，この知識を利用して不要な構造の生成を 
出来る限り避ける方が遥かに効率よく目標に近づくこと が出来るからである.物理的な「物」は樣々な物理法則 に従う. 光れらを満たすもののみが実現可能だから，こ の法則を知識化し，利用することによって，効率的に設 計を進めるのがトップダウン設計である . 一方 , ソフト ウエアには汎分野性があり，一般にはぞのような物理的 制約を持たない．普遍的な数学的あるいは論理的法則が あるが, 相対的に少数である. 従って構造作成時に効果 的に不要構造を除去する性質を知識化することが困難で あり, 必然的に行為構造の作成は相対的にボトムアップ 設計の性質を強くする．

[2] 一般の設計とプログラム設計は, 要素から行為構 造が作られる際の組み合わせ爆発の程度が全く異なる． 要素が 3 次元の物体である時は, 2 要素間の結合でも異 なる効果を生じる組み合わせ方に一般的な構造制約はな いから，時には無限に近い，例えば位置関係がわずかに 異なる 2つの構造に機能の相違か現れる .これに対し， 行為要素は有限の入出力ポートを通してのみ相互結合さ れるという構造的制約があり，2 要素間の結合法は有限 である. 要素数が有限なら全体の組み合わせ数も有限で ある

ボトムアップ構造作成の場合, 可能なあらゆる構造を 作り, 評価して最適なものを残せば良い.しかし有限と 言っても現実には場合の数は大きく，人間によるプログ ラム開発ではこれは困難であり，個人的な見通しに基づ いて作った特定の構造が基本になる . しかしこのように して作られた要求·仕樣が正しいものである保証はない . しかるにソフトウェア開発の上流過程でこの誤り検出が 困難である．

知的システムを用いてプログラム開発を行うにはこ のような問題を解決するための方法論，すなわち正しさ の保証された行為構造 (概念構造) を作る方法を提供す る必要がある . これは要素の組み合わせとして作られる 多くの行為構造の中から応用分野の要求を満たす正しい 解を速やかに選ぶことである. 光れでも要素の数が多い 時は実用的な困難が生じるので, 適切な対応策が必要で ある. 弚の第 1 は機能の適切なマクロ化によって多層化 し, 各層内の要素数を減らす. 最初に階層構造を作るの はこのためである . 設計の多層化は機能に基づいて対象 一要素間に part-of 関係を生成することであり，これに ついては一般設計とプログラム設計の差はなく，プログ ラム設計でも応用分野における知識やプログラムの機能 的構造に関する知識の範囲内で全体機能の分割がトップ ダウンに行われる．これは例えば企業において必要な処 理の単位が大きいとき，これを分割し，複数の人間で分 散的に実行することを考えれば良い．次いで各層内の設 計が breadth-first に行われる .

第 2 は可能な構造の中から条件に合うものの選択を 自律的に行うことである. 弚れには細部までの明示的表 現と光の処理が必要であり，(a) 要素の組み合わせ構造
(グラフ構造) の生成と，(b) 生成された構造の中から 条件に合うものの選択，を自律的に行うことになる．前 者はアルゴリズミック行われるが , 後者に付いては選択 の知識が必要である. (b) の機能が充実していれば， (a) ではあらゆる可能な構造を生成することも可能で ある .

人間が行う場合，経験に基づいて巧みに構造を作って しまうため, 選択の方法が明示化されていない .これを 明示し知識化できれば候補構造の絞り込みを自動的に行 うことが出来る．ただし一つに絞り込まれる保証はない ため, 最終的には最適に近いものを選ぶ手段としてのシ ミュレーションが必要になる．今日，乥れを開発手順に 含まれているものに組み込み型のプログラミングがある . そこでは HILS (Hardware in the Loop Simulator) と 呼ばれるシミュレータが不可欠な要素としてプログラミ ングに含まれる[HAN96] .このように候補構造の生成と 絞り込みおよびシミュレーションの方法を自律化するこ とによってプログラムの自律的設計が可能に成る .

\section{§ 3 整合的でない構造の除去}

応用分野との対応を持たない基本プログラムは別に して，応用プログラム開発には分野固有の知識を使える ので，乥れを構造の絞り込みに用いることができる．筆 者らはこれについて, ( i )入力一出力結合によって生じ る構造の整合性チェック, ( ii ) 変数の変域関係による構 造矛盾のチェック , ( iii ) 変数の型チェックを拡大した意 味チェック，などの可能性を試みている .

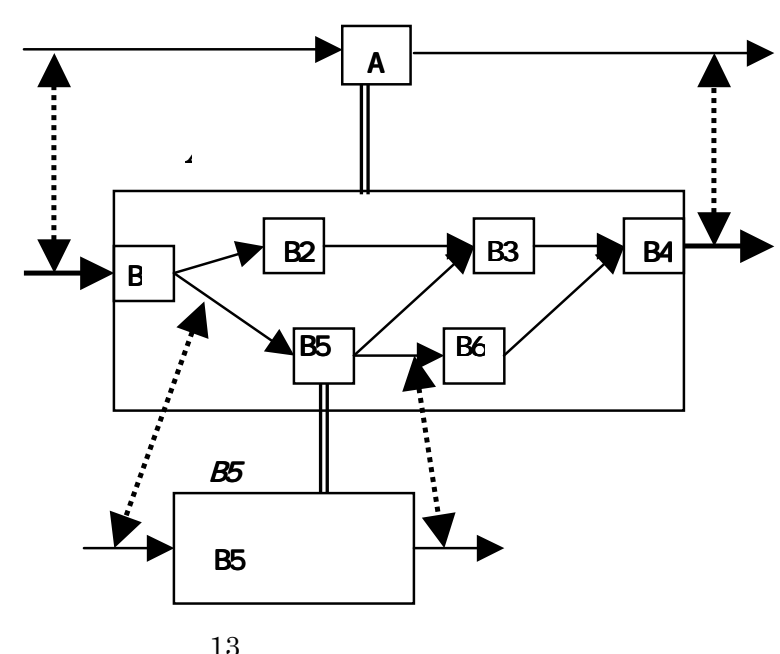

（ｉ）は可能な行為構造のうち構造的に整合的でないも のを除去することによって絞り込みを行う．例えばある 行為 (関数) の出力の結合先がない構造は不整合構造で ある. 入力一出力結合によって作られる構造は, 最初は すべて整合的に作られても，構造内の一つもしくは複数 の結合が ( ii ), ( iii ) のチェックで消去された場合， 兴の影響が構造内に伝播的に広がり，遂には不整合構造 になる，不整合構造をすべて除去することにより，構造 
の絞り込みが行われる，不整合構造による絞り込み効果 は一般に大きい .

この構造不整合を引き起こすのは ( ii ) , ( iii ) のチ ェックによる個々の結合の除去である. 各行為の入力 , 出力変数は整数, 少数などの一般的な型のほかに問題に 応じて一定の変域・值域を持つ. 結合される行為間でこ の変域一值域間に一定の関係が保たれねば成らない． ( ii )では，光れが保たれないものの結合か除去される . 更に情報処理の基本関数は可能な限り分野の固有性を除 いた普遍的な機能を果たすものとして開発され，変数の 型も数学的な定義に限定されていても，二れを現実の問 題に応用する際, 分野の色が付く.この時点て変数は応 用依存の物理的 (弚の他の) 意味を持つ.これが(iii)で ある. 意味はいくつかの型に分類される. 外部変数が行 為構造に入力された時, 入力変数の持つ意味が処理内容 に応じて变換され, 出力变数の意味が定義される. 結合 される行為間で变数の意味型が合わないものは原則的に は不整合結合である、簡単な例を挙げる . ある行為は， 2 入力と, 乥の積を求める数学的演算行為を持つとする. これは数学的な定義である.応用に際して产の入力変数 に「長さ」という意味型をもつ物理量が与えられたとす る.この時, 出力ば 長さ×長さ’すなわち「面積」と いう意味型を持つ，もし，この出力が他の行為の，「面積」 以外の意味型を持つ変数, 例えば「重さ」を表す変数に 結合されていたら，この結合は不整合であり，除去され る.

これは物理における次元解析の概念であり，直交的な 基本概念から基本の意味型記号が定義され, 乥れから複 合概念の意味型が表現される.例えば，L; 長さ，M ; 質 量, $\mathrm{T}$; 時間を基本概念とすると, $\mathrm{L}^{2}$; 面積, $\mathrm{L}^{3}$; 体 積, $\mathrm{L} \cdot \mathrm{T}^{-1}$; 速度 $\mathrm{L} \cdot \mathrm{T}^{-2}$; 加速度, $\mathrm{M} \cdot \mathrm{L} \cdot \mathrm{T}^{-2}$; 力，などである.この概念を物理的対象以外にも拡張す ることを試みる。例えば $\mathrm{P} ;$ 1 単位当たり価格， $\mathrm{V}$; 量, とすると， $V \cdot P$; 価格である. 行為構造は前もって準 備されている要素行為から構成されるものとし, 要素行 為を定義する時に入力一出力間の意味的関係をもたらす 構造関係を, 例えば, 出力 $i=\lambda 力 1^{p} \cdot \lambda 力 2^{a} \cdots-\lambda$ 力 $\mathrm{m}^{\mathrm{r}}$ の樣に表して, 行為の付加情報として準備してお くことができれば，この入力に意味コードを代入して出 力の意味コードか容易に求まり，このチェックが可能に 成るであろう、以上の議論は応用プログラム開発に際し， プログラムという具体的な特性を持たない（抽象的な） ものを応用分野に結び付ける際に，応用分野の物理的な 性質等を反映させることによってプログラムの開発を助 ける方式を示したものである .

これは一つの試みであり，筆者らはこの一部を実験的 に確かめたが, 今後の研究に俟つところが大きい .この 問題はソフトウエア開発を含めて, 上流の問題解決から 最終解 (プログラム開発の場合はコード生成) まで, 一 貫して行う方式が必要であることを示している[ 21] と言
う点で今日の情報技術全般の問題であることを示す例と して用いたものである.

\section{5. 言語とシステム構成例}

現実に生じる問題は多くの分野にまたがり，多樣な概 念の複合体として現れる.人間が問題解決できるのは, これら多樣な概念を理解し適切に利用しているからであ る.予見できない問題を含め, 人間の問題解決を全的に 支援する新しい情報システムは, 人間と, 人間が扱う対 象に関わる多樣な概念を現実にあわせて複合的に表現し 処理可能にせねばならない，乥れには多樣な基本概念を 記述し，かつ処理する言語が必要である。

これまでの例からも容易に想像できるように，この言 語は樣々な概念を表す記述力が必要である．これにはど のような基本概念の表現が必要であるかを，応用の分析 を含めて検討せねばならない，筆者らは可能な範囲の分 析を通して，光のような実験的言語を開発し，光れを用 いて実験を行った .これまでに述べてきた問題解決シス テムの基本は概念的モデルにあり，モデル内の行為や属 性は宣言的に記述されることによって随時新しい行為や 属性を付加・削除できることが重要な特性になっている． 従ってこの言語は宣言的言語であることが基本条件であ る. 同時に , モデルにおいて構造の概念が重要な意味を 持つ. 何故なら問題解決の基本は機能- 構造関係の処理 にあるからである . 従って言語は構造の記述能力が高い ものであることが要求される. 概念モデルは主体 - 行為 一対象からなる概念ユニットを基本に構成されるが，こ の要素ごとに階層構造が作られる. 行為の階層はメタ行 為の概念を表しており，この表現にはメタ記述が必要に なる.これも言語への要求になる.

この言語記述は処理可能でなければならず，光のため の処理系が必要である. 宣言的言語であることから，こ の処理系は推論を主体としたものになるが, 単純な記号 マッチングに基づく推論エンジンでは不十分で, 内部に 構造の処理を含む高度の処理系が要求される.このよう な記述一処理システムとして筆者等は KAUS (Knowledge Acquisition and Utilization System) と名付けたシステ ムを開発した .KAUSはこれまで述べてきたモデル化方式， 問題のモデル表現 (概念構造), 知識の表現, 問題向き知 識の収集方法, 問題分割・分散などの諸概念を表現でき ることを目標として進化させてきたシステムである [OHS 85，YAM 95，YAM 00].これを用いて筆者らが 開発してきた実験システムの概要を図 14 に示す このシ ステムはKAUSを前提にして始めて実現が可能になった ものである .このシステムを用いて基本概念の実証実験 を行った 結果はこの方法の正当性を示すものであった . 


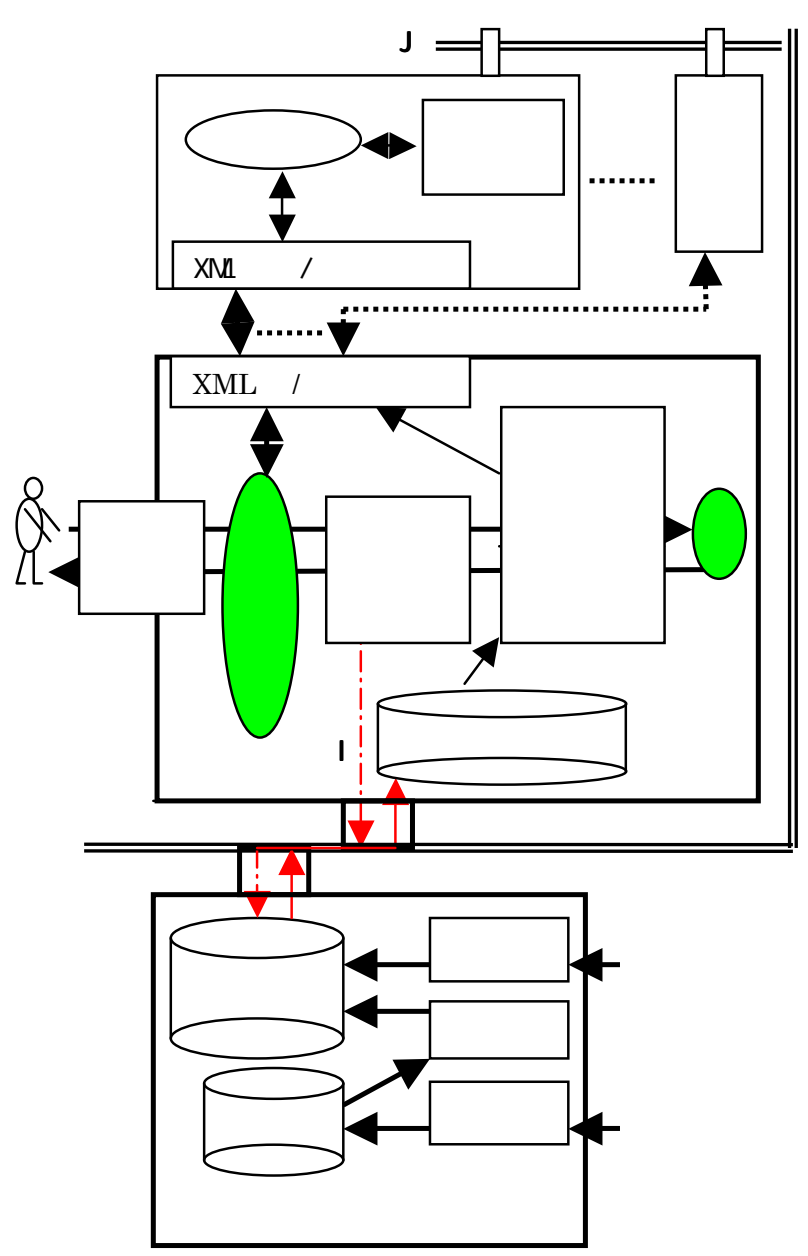

図 14 新情報システム構成図

\section{6. むすび}

問題の複杂倠化，大規模化は現代の大きな特徵であり， それに誘起される問題は将来社会の最大問題の一つにな る可能性がある . 複杂隹化の傾向にいち早く反応している のは経済分野で, 対応策が模索されている[GUN 00 ,DIA 97]が,乥の原因である社会組織の複雑化をもたらした最 大の要因は急速な技術発展にある. 光して技術や光れに 関わる人間を含む管理組織の複雑化に人間が対応できな くなっている．近年発生している大型システムの事故の 多くはここに有ると考えられる．弚の対応を急がねばな らないが, このような問題の複雑化, 大規模化には新し い情報技術で対応するほかない．

問題解決はすべて自動化される訳ではないから，必ず 人間か関わってくる. 実世界では問題解決を多くの人が 分担する方式が一般化している .この全体が問題解決の 構造を表す．この構造は一度でうまく作られる訳ではな いため, しばしば再構築が行われる. 再構築に応じて人
の移動が伴ったりする .これまで人間が行う問題解決が うまく行われてきたのは，このような動的な概念構造の 構築, 修正, 再構築が人間の能力の範囲内で可能だった からでもある．このような複雑な問題解決に情報システ ムを利用するには , 情報システムがこのプロセスを制約 することがないような形で開発されることが不可欠であ る.しかし問題の大型化によってこれを満たすことが困 難に成ってきている .

問題解決に情報システムを利用するということは，問 題解決の構造をコンピュータ内に表現し , 実行すること である .これまでは光れをコンピュータの仕組みに基づ いて, プログラムという形式で問題解決の構造の一部を 表現してきた . コンピュータ内の表現と現実の問題解決 の構造では大きな差がある . この差が大きい程 , コンピ ユータ化が困難になり，コンピュータの表現でカバーす る範囲が狭くなり, コンピュータ化の効果が減少する . このような状況に情報技術面で対応するためのアプロー チとして , オブジェクト指向やマルチ・エージェント・ システムなどのパラダイムが出現した . 表面的にはこれ らの方式で表現されたものは人間の問題解決方式と似て いるが, 概念構造を作る時の動的な問題解決過程は, 現 実の世界で行われているものと，これらパラダイムを用 いてコンピュータ内で表現されるものとの間には大きな 相違がある . 光のため, 情報システムの専門家が間に入 らなければならない .

問題解決の中に情報システムの専門家が入ることに よって，無事システム開発が行われている間は良いが， 情報システムの専門家は必ずしも実世界の問題に関する 専門家ではないから，常にこの間のギャップによる誤解 が付きまとい, 開発されたシステムの正当性が保証され ない . 問題が大規模・複杂倠になるほどこれは大きな問題 になる . 実世界での上記の問題解決プロセスに通じた ユーザが自身で情報システムを構築することか理想であ る.

これに必要なのは正しいモデルの概念である．複雑・ 大規模な問題解決には，関連する多くの概念を包括的に 表すモデルの作成が不可欠であるが，この樣な統合モデ ルの研究はこれまでなされておらず，一部実践として情 報化のためのビジネス業務のモデル化の試みがなされた に過ぎない[GOT 97] .

本稿では前半で問題を正しく表現することの重要性 と解の正当性を保証する方式に付いて述べ, 後半では光 れを実現するために，実世界で行われるプロセスに適合 する情報システム開発方式として, 人間が問題を概念モ デルとして表し , 柔軟に定義可能な問題解決ブロックを 用いて , 概念モデルと同形の情報システムをビルデイン グ・ブロック方式で自律的に作り上げる方法と光の為の 新しい情報技術の研究を行った . ブロック内では知識処 理が行われ, 概念モデル内で置かれた位置に応じて定ま るブロックの役割 (機能) は, 与えられる問題のモデル 
に基づいて, 关の問題を解決する上で必要な知識を収集 することによって達成される.これによって柔軟で動的 な構造化を保障することが出来る．このような方式は新 しいものであるため, 未だ多くの課題を残しているが， 方式として実現可能であることは実験的に示されている . この実用化にはこの基本構想を充実するための，周辺ソ フトウエア整備が必要である.

最後に付言するが , 今日ソフトウエア開発に関してモ デリングの概念に関心が高まっている.この方法は目的 とするソフトウエアを生成するために, 対象の必要な範 囲あるいは側面をまずモデル化することによって開発の 見通しをつけるアプローチと言ってよい，モデルは一過 性の存在であり，異なるソフトウエア開発間で共用性は 乏しい．これはソフトウェア開発を単独の閉じた行為と することを原則とするからで，モデルと言う中間的な生 成物の比重を減らすことが重要である.この事情は多か れ少なかれ他の開発問題でも同樣である.

本稿の考え方は基本的にこれと異なる . 問題ごとに一 過性のモデルを作る方式は, 今後技術面からも，トータ ルなコストの面でも困難になり，多くの問題に共通の基 盤となるモデルの構築法を与えることによって, 資産と してのモデルと，弚れに関連して体系化される知識を共 有する方式が今後不可欠になると言うのが本稿の立場で ある .この方式を立ち上げるためには初期の投資が大き いため, 組織による開発が必要になる。

\section{参考文献}

[ARA 01] 新谷虎松 ; 特集「マルチェージェント技術における 新しい可能性」, 人工知能学会誌, Vol.16, No.4(2001)

[DIA 97] 週間ダイヤモンド編集部, ダイヤモンド・ハーバー ド・ビジネス編集部共編, 京都大学経济研究所・複杂倠形経済 システム研究センター協力 ; 複䧱形の経济学[入門と実践] , (1997)

[GOT 97] 後藤靖国 ; 業務知識と情報システムーモデル・統合 業務システム , 講談社出版サービスセンター, (1997)

[GUN00] グンター・パウリ (近藤隆文訳) ; アップサイジン グの時代が来る，朝日新聞社，(2000)

[HAN 96] H. Hanselmann; Hardware-in-the-Loop Simulation Testing and its Integration into a CACSD Toolset, IEEE Int. Symp. Computer-Aided- Control System Design, (1996)

[HUH 97] Readings in Agents (Edited by M. N. Huhns \& M. P.Singh), Chapter1; Agents and Multi-agent Systems, Themes, Approaches, and Challenges, (1997).

[IPJ 04] 情報処理＼cjkstart特集モデリングとツールを駆使したこ れからのソフトウエア開発技法一モデル駆動開発手法を中 心として一, 情報処理, Vol.45, No.1, 通巻 467 号 , (2004)

[KEY 02] Kevin L. Mills and Hassen Gomaa;

Knowledge-Based Automation of a Design Method for Concurrent Systems, IEEE Trans. On Software Engineering, Vol.28, No.3, (2002)

[KON 01] 河野浩之 ; 特集「Web システムにおける情報獲得支 援技術」，人工知能学会誌，Vol.16, No. 4, (2001)

[MIZ 99] 溝口理一郎; オントロジー研究の基礎と応用, 人工知 能学会誌 Vol.14, No.6, (1999)
[MUR 01] G.C. Murphy, D. Notkin and K.J. Sullivan; Software Reflexion Models: Bridging the Gap between Design and Implementation, IEEE Trans. on Software Engineering, Vol. 27, No.4, (2001)

[OHS 85] S. Ohsuga \& H. Yamauchi ; Multi-Layer Logic -A Predicate Logic Including Data Structure as Knowledge Representation Language, New Generation Computing, Vol. 3, 403-439, (1985)

[OHS 96] S. Ohsuga ; Multi-Strata Modeling to Automate Problem Solving Including Human Activity, Proc.Sixth European-Japanese Seminar on Information Modelling and Knowledge Bases, (1996)

[OHS 98] S. Ohsuga ; Toward Truly Intelligent Information Systems - From Expert Systems To Automatic Programming, Knowledge Based Systems, Vol. 10, (1998)

[OHS 99] S. Ohsuga ; A Modeling Scheme for New Information Systems -An Application to Enterprise Modeling and Program Specification, IEEE International Conference on Systems, Man and Cybernetics, (1999)

[OHS 01] S. Ohsuga ; ; How Can AI Systems Deal with Large and Complex Problems? International Journal of Pattern Recognition and Artificial Intelligence, Vol.15, No.3, (2001)

[OHS 01b] S. Ohsuga and H. Ohshima;A Practical Approach to Intelligent Multi-Task Systems - Structuring Knowledge Base and Generation of Problem Solving System, $11^{\text {th }}$ European-Japanese Conferene on Information Modelling and Knowledge Base, (2001)

[PAO 02] M. Paolucci, T. Kawamura, T.R. Payne and K. Sycara ;Semantic Matching of Web ervicesCapabilities, Proc. $1^{\text {st }}$ Semantic Web Conference (ISWC002), (2002)

[ROS 97] F. H. Ross; Artificial Intelligence, What Works and What Doesn't ? AI Magazine, Volume 18, (1997)

[SYC 98] K.P. Sycara; Multiagent Systems, AI Magazine, AAAI, Summer , 79-92, (1998)

[WAY 94] W. Wayt Gibbs; Software Chronic Crisis, Scientific American, Volume 18, No.2, (1994)

[YAM 95] H. Yamauchi ; KAUS6 User's Manual, RCAST, University of Tokyo, (1995)

[YAM 00] H. Yamauchi and S. Ohsuga; A Method and Language for Constructing Multi-agent Systems, International Symposium on Methodology of Intelligent Systems (ISMIS), (2000)

[YAT 99] 山口高平編; 論文特集「オントロジー研究の基礎と 応用」人工知能学会誌 Vol.14, No.6, (1999)

[YOS 03]吉岡真治編; 特集「Intelligent Manufacturing Systems:IMS」,人工知能学会誌 Vol.18, No.2, (2003)

\section{〔担当委員 : 溝口 理一郎〕}

\section{3 年 10 月 16 日 受理}

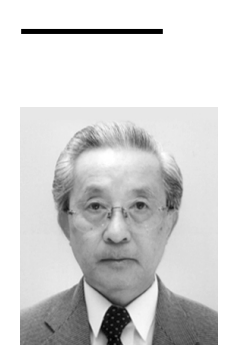

\section{者 紹 介}

大須賀 節雄 (名誉会員)

1957 年東京大学工学部航空学科卒業,富士 精蜜工業株式会社入社, 1961 年東京大学航 空研究所助手,1966 年東京大学宇宙航空研 究所助教授, 1981 年東京大学工学部境界領 域研究施設教授, 1991 年東京大学先端科学 技術研究センター長, 1992 年東京大学学際 工学専攻教授, 1995 年東京大学定年により退官, 早稲田大学理 工学部情報学科教授, 2000 年早稲田大学理工学研究科客員教授, 2003 年早稲田大学退職. 知識科学, 知能システム, データから の知識発見, 自動プログラミング等に従事 . 